\title{
INDIVIDUAL MINERAL SUPPLEMENT INTAKE BY EWES SWATH GRAZING OR CONFINEMENT FED PEA-BARLEY FORAGE
}

\author{
by
}

Devon Lynn Ragen

A thesis submitted in partial fulfillment of the requirements for the degree

of

Master of Science

in

Animal and Range Sciences

MONTANA STATE UNIVERSITY

Bozeman, Montana

April 2012 
CCOPYRIGHT

by

Devon Lynn Ragen

2012

All Rights Reserved 


\title{
APPROVAL
}

\author{
of a thesis submitted by \\ Devon Lynn Ragen
}

This thesis has been read by each member of the thesis committee and has been found to be satisfactory regarding content, English usage, format, citation, bibliographic style, and consistency and is ready for submission to The Graduate School.

Dr. Janice G. P. Bowman

Approved for the Department of Animal and Range Sciences

Dr. Glenn C. Duff

Approved for The Graduate School

Dr. Carl A. Fox 


\section{STATEMENT OF PERMISSION TO USE}

In presenting this thesis in partial fulfillment of the requirements for a master's degree at Montana State University, I agree that the Library shall make it available to borrowers under rules of the Library.

If I have indicated my intention to copyright this thesis by including a copyright notice page, copying is allowable only for scholarly purposes, consistent with "fair use" as prescribed in the U.S. Copyright Law. Requests for permission for extended quotation from or reproduction of this thesis in whole or in parts may be granted only by the copyright holder.

Devon Lynn Ragen

April 2012 


\section{ACKNOWLEDGEMENTS}

There are so many people I would like to thank for their support, guidance, and dedication in helping me complete my thesis. I would like to first thank Dr. Jan Bowman and Dr. Pat Hatfield for your endless hours assisting me in the field, in the lab, and in writing my thesis. Your leadership, direction and encouragement provided me with the motivation and inspiration to do my best and try my hardest in every aspect of my graduate career. Thank you Dr. Rachel Endecott and Dr. Mark Petersen for serving on my committee and examining my thesis.

I would also like to thank my family for your support in my decision to work towards my Master's Degree. You have always been behind my decisions and encouraged me to follow my dreams. All of the graduate and undergraduate students that helped with the data collection process deserve a huge thank you: Joy, Melissa, Gill, Kellen, Jill, Megan, Thomas, Emmett, Nick, we couldn't have done it without you. Dr. Hayes Goosey, Dr. Zach Miller, Mo, Tess, Liz, Alison, Susan, Allison, the BART Farm and Red Bluff crew, Wendy and the group at the Fish Tech Center, and the team at the Bair Ranch are owed an enormous thank you as well for your participation in my project.

My husband, Tyler, deserves a thank you for not only helping in the field but reading my thesis and listening to my presentations over and over again. Erin, none of this would have been possible if you hadn't been my "partner in science." I am so glad that we were able to help each other through the whole process with laughs and tears. Thank you for absolutely everything you have done. 


\section{TABLE OF CONTENTS}

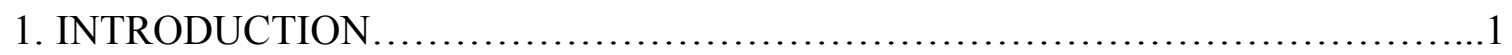

2. LITERATURE REVIEW ..................................................

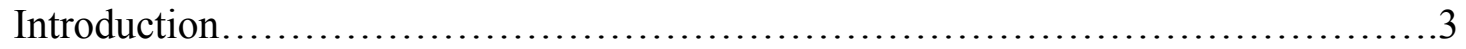

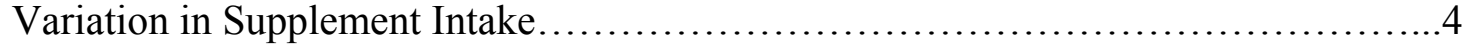

Mineral Supplements....................................................6

Methods for Estimating Supplement Intake by Grazing Animals.................8

Animal-Related Factors................................................ 9

Social Interactions............................................ 9

Age.........................................................9

Previous Experience..........................................10

Individual Requirements...................................... 11

Individual vs. Group Feeding. ...................................11

Supplement-Related Factors .......................................... 12

Supplement Form............................................12

Supplement Formulation........................................15

Supplement Allowance......................................... 18

Trough Space...................................................19

Environmental Factors.................................................20

Soil Fertility and Forage Type Consumed...........................20

Season of Year..................................................20

Availability of Protein-Energy Supplements..........................20

Salt Content of Drinking Water...................................21

Palatability of Mineral Mixture ...................................21

\section{MINERAL SUPPLEMENT INTAKE, FORAGE INTAKE, AND}

PERFORMANCE BY EWES .............................................23

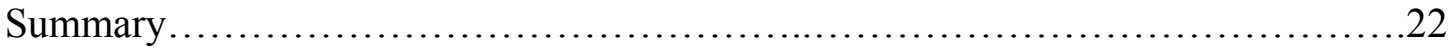

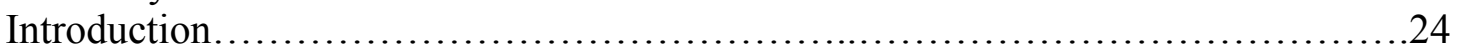

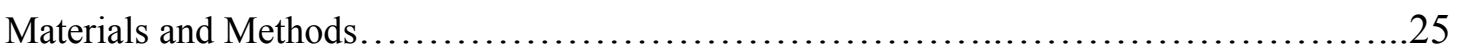

Sheep Selection and Management....................................... 25

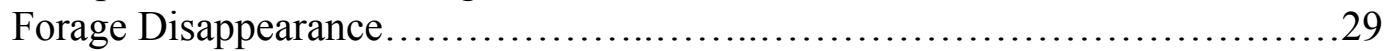

Forage Composition..................................................... 30

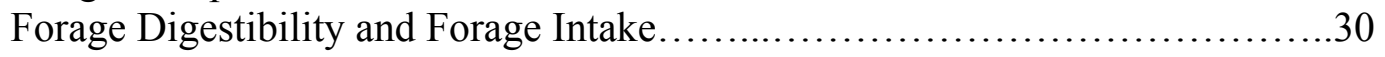

Mineral............................................................. 33

Statistical Analyses.................................................. 34 


\section{TABLE OF CONTENTS-CONTINUED}

Results and Discussion................................................... 34

Forage Quality and Production........................................... 34

Forage Intake and Ewe Performance........................................34

Mineral Supplement Intake.............................................. 35

Distribution of Mineral Supplement Intake.................................38

Summary and Implications.............................................. 40

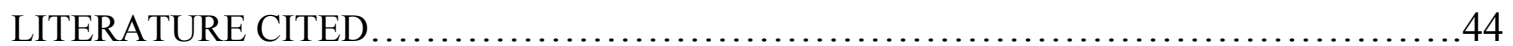




\section{LIST OF TABLES}

Table

1. Composition of mineral supplement provided ad libitum with a target intake of $7.09 \mathrm{~g} \cdot \mathrm{ewe}^{-1} \cdot \mathrm{d}^{-1}$ (values provided by manufacturer)

2. Treatment location, pasture size, forage production, composition and in vitro dry matter disappearance of pea-barley forage in swaths, standing stubble, and baled hay consumed by ewes in one of two treatments, confinement or pasture, with a mineralsupplement provided ad libitum (based on clipped samples)

3. Performance, forage dry matter intake, and mineral-supplement intake by ewes in one of two treatments (pasture or confinement) swath grazing or confinement-fed pea-barley forage

4. Mineral supplement intake distribution by ewes in one of two treatments grazing pea-barley forage in swaths or bale-fed in confinement 


\section{LIST OF FIGURES}

Figure

1. Photographs of mineral feeders

2. Aerial View of Fort Ellis Research Station with diagram of zoomed in individual plot area. 2010 grazing plots $=110,215$ and 303. 2011 grazing plots $=106,211,301$

3. Photograph of one of the three swath-grazing plots before grazing .

4. Photograph of the three confinement pens with sheep eating at hay feeders.

5. Individual ewe mineral intake (g/d) in 2010 and 2011. Target intake was $7.09 \mathrm{~g} / \mathrm{d}$. 


\section{ABSTRACT}

Sixty mature ewes (non-pregnant, non-lactating) were used in a completely randomized design to determine if feeding method of pea-barley forage (swath grazing or hay in confinement) had an effect on individual ewe mineral consumption and variation in supplement intake. Thirty ewes were randomly allocated to 3 confinement pens and 30 ewes were randomly allocated to 3 grazing plots. The study was conducted September 25 to October 15, 2010 and September 6 to 19, 2011. Targhee ewes (65.4 $\pm 5.84 \mathrm{~kg} \mathrm{BW})$ were used in 2010. Rambouillet ewes $(61.9 \pm 6.28 \mathrm{~kg} \mathrm{BW})$ were used in 2011. Ewes had ad libitum access to food, water, and a mineral supplement containing 11 to $12.5 \%$ salt with $2 \%$ titanium dioxide added as an external marker to estimate individual mineral intake. Forage intake was calculated using estimates of fecal output obtained by dosing gelatin capsules containing $2 \mathrm{~g}$ chromic oxide every day for $14 \mathrm{~d}$, and in vitro 48-h DM indigestibility. Fecal grab samples were collected from each individual ewe for a period of $7 \mathrm{~d}$ and composited by ewe. Forage and mineral intakes were analyzed using individual ewe as the experimental unit. A year $\times$ treatment interaction $(P$ $<0.01)$ existed for forage DMI and mineral DMI. Ewes in confinement consumed more forage than grazing ewes in 2010 ( $2.60 \mathrm{vs} .1 .86 \mathrm{~kg} / \mathrm{d}$, respectively), but less than grazing ewes in 2011 (1.99 vs. $2.49 \mathrm{~kg} / \mathrm{d}$, respectively). Mean mineral intake was highest $(P<$ 0.01 ) by grazing ewes in 2011 and 2010 (average $69 \mathrm{~g} / \mathrm{d}$ ), intermediate by ewes in confinement in $2010(57 \mathrm{~g} / \mathrm{d})$, and lowest by ewes in confinement in $2011(31 \mathrm{~g} / \mathrm{d})$. A year $\times$ treatment interaction $(P=0.05)$ existed for mineral DMI CV. Mineral DMI CV was higher $(P=0.04)$ for the confinement treatment than the grazing treatment in 2011 (67.2 vs. 33.7\%), but similar for confinement and grazing treatments in 2010 (55.4 vs. $46.5 \%$, respectively). In this study, both swath grazing ewes and ewes in confinement consumed more mineral than recommended by the mineral manufacturer and the NRC indicating that more research is needed to develop a better understanding of the factors that regulate and impact mineral intake. 


\section{INTRODUCTION}

In Montana, ewes typically consume 14 to $28 \mathrm{~g}$ of mineral supplement per day, which results in an annual cost per ewe of $\$ 4.49$ (Kott, 2005). Since feed and supplement costs can be more than $50 \%$ of total operational costs for range livestock producers (USDA, 1994), monitoring supplement intake, and making sure animals receive the appropriate amount of nutrients, could reduce production costs. Substantial variation in individual animal intake of protein and energy supplements has been reported (Bowman and Sowell, 1997; Sowell et al., 2003). The type of supplement offered to cattle and sheep, the conditions under which it is fed, previous experience with supplements, social interactions, and forage quality and availability has been shown to influence the amount of supplement consumed by individual animals such as cattle and sheep (Bowman and Sowell, 1997).

As an example, Curtis et al. (1994) found that grazing Merino wethers, offered a self-fed lupin seed supplement, had an extremely wide range of intakes. Thirty-three percent consumed less than $150 \mathrm{~g} / \mathrm{d}$, and $8 \%$ consumed over 1,200 g/d. Sixty-one percent of the wethers did not meet the target supplement consumption, and the CV of individual supplement intake was $83 \%$.

While researchers have looked at individual intake of protein and energy supplements, few studies have attempted to evaluate variation in individual consumption of salt/mineral mix supplement. Cockwill et al. (2000) evaluated individual intake of mineral and molasses supplements in cows, heifers and calves. They reported that the average individual intake was $445 \mathrm{~g} / \mathrm{d}$ with a range of 0 to $1,650 \mathrm{~g} / \mathrm{d}$. However, there is a 
lack of information on the variation in salt/mineral mix supplement intake, especially in sheep. There is also a lack of information comparing sheep grazing swaths or fed the same forage in confinement.

The objective of this study was to determine if forage feeding method (swath grazing or the same forage in hay form fed in confinement) has an effect on individual animal consumption and variation of a salt/mineral mix supplement. We hypothesized that individual salt/mineral mix supplement intake does not differ by ewes grazing or confinement-fed pea-barley forage. 


\section{LITERATURE REVIEW}

\section{$\underline{\text { Introduction }}$}

Supplements provided to grazing animals can be classified into three general categories: 1) energy; 2) protein; and 3) minerals (Allden, 1987). Producers often feed trace mineralized salt to grazing sheep ad libitum or just during critical times like flushing, lambing and lactation. In order for mineral supplementation programs to be effective, each animal must consume the target amount of supplement to ensure desired nutrient intake. Variation in individual supplement intake may explain some of the inconsistent responses to supplementation (Kincheloe, 2004).

The type of supplement offered and how it is fed have been shown to influence individual supplement intake, and variation in supplement intake can lead to inconsistent responses to supplementation (Bowman and Sowell, 1997). Factors affecting intake variation include formulation and palatability, level of competition, social interactions, and forage quality and availability (Bowman and Sowell, 1997). Several studies have also reported that supplement consumption may be influenced by animal-related factors such as previous experience and feeding situation (Distel et al., 1994; Dixon et al., 2001; Taylor et al., 2002).

Common measures of variation for individual supplement intake include the coefficient of variation (CV), proportion of non-feeders (animals consuming little or no supplement), proportion of animals consuming target supplement intake, and proportion of animals over-consuming supplement. Substantial variation in individual animal intake 
of protein and energy supplements has been reported (Sowell et al., 2003, Bowman and Sowell, 1997).

While researchers have looked at individual intake of protein and energy supplements, few studies have attempted to evaluate variation in individual consumption of a salt/mineral mix supplement.

\section{$\underline{\text { Variation in Supplement Intake }}$}

The effectiveness of most supplementation programs is based on a target amount of supplement intake per animal (Kincheloe, 2004). The target amount is formulated to deliver a specific amount of minerals and/or other nutrients. Potential negative impacts exist for animals consuming on either side of the target intake amount (Bowman and Sowell, 1997).

Most producers measure supplement intake by disappearance which does not take into account the intake of individual animals. Regardless of supplement form or delivery method, variation in individual supplement intake exists and may contribute to inconsistent results to supplementation (Bowman and Sowell, 1997). The coefficient of variation $(\mathrm{CV})$ is used in scientific literature to quantify variation in intake.

In a review of delivery method and supplement consumption by grazing ruminants, Bowman and Sowell (1997) reported an average CV for individual supplement consumption of $79 \%$ for blocks, $23 \%$ for liquids, and $41 \%$ for dry supplements. The percentage of non-feeders was $14 \%$ for blocks, $23 \%$ for liquids, and 
$15 \%$ for dry supplements across a range of animals, environments, and supplement formulations.

Curtis et al. (1994) found that grazing Merino wethers, offered a self-fed lupin seed supplement, had an extremely wide range of intakes. Thirty-three percent consumed less than $150 \mathrm{~g} / \mathrm{d}$, and $8 \%$ consumed over $1,200 \mathrm{~g} / \mathrm{d}$. Sixty-one percent of the wethers did not meet the target supplement consumption, and the $\mathrm{CV}$ of individual supplement intake was 83\% (Curtis et al., 1994). Cockwill et al. (2000) evaluated individual intake of mineral and molasses supplements in cows, heifers and calves. They reported that the average individual intake was $445 \mathrm{~g} / \mathrm{d}$ with a range of 0 to $1,650 \mathrm{~g} / \mathrm{d}$.

Tait and Fisher (1996) offered a commercially available mineral product (mixed with salt in the proportion of one part mineral to one part salt) to 20 Holstein yearling steers. All animals in the group consumed the mineral mixture on a regular basis. Tait and Fisher (1996) reported the average intake to be $135 \pm 55 \mathrm{~g} \bullet$ steer $^{-1} \bullet \mathrm{d}^{-1}$. The range was from about 50 to $300 \mathrm{~g} / \mathrm{d}$; however, the majority of the animals were consuming between 100 and $200 \mathrm{~g}$ of the mineral-salt mixture.

Factors influencing consumption of mineral mixtures include: soil fertility and forage type, season of year, available energy and protein, individual requirements, salt content of water, palatability of mineral mixture, availability of fresh minerals and physical form of minerals (McDowell, 1996). 


\section{$\underline{\text { Mineral Supplements }}$}

Minerals play many different roles in an animal's body. They are important for animal structure, metabolism, reproduction, immune function, and maintaining electrolyte balance. In the wild, animals will utilize mineral deposits as salt licks, and pica, including bone chewing to consume the minerals they need to survive (Theiler et al., 1924). All livestock have an innate attraction to salt and this behavior is used to supplement animals with trace minerals (Burghhardi, 1982). Livestock consume minerals through the forages they eat, the water they drink, and also from producer supplementation. Producers often feed trace mineralized salt or a mineral supplement containing salt ad libitum to sheep (McDowell, 1996).

Sheep that are salt deprived will consume less feed and water. Minerals can be supplemented to animals in different forms using salt as an attractant. Sodium, chlorine, calcium, phosphorus, magnesium, potassium, sulfur, cobalt, copper, iodine, iron, manganese, molybdenum, selenium and zinc are all minerals found to be essential in sheep. (Kott, 2005). Forage and water mineral analysis is critical for determining intake (Greene, 2000).

The common trace mineralized salt fed to sheep contains seven of the fifteen essential minerals that sheep require: sodium, chlorine, iodine, cobalt, iron, manganese and zinc (Kott, 2005). Potassium, magnesium, iron, copper and manganese are usually readily available in feedstuffs. Sodium chloride and phosphorus are the minerals most likely to be deficient under normal grazing conditions (Kott, 2005). In certain areas of Montana and the United States, selenium may also be deficient (Kott, 2005). 
White et al. (1992) reported that wethers offered a loose mineral lick had increased BW by $4.5 \mathrm{~kg}$ during summer, increased clean fleece weight by $240 \mathrm{~g}(9 \%)$, and increased wool staple strength by $15 \mathrm{~N} / \mathrm{kt}(40 \%)$ compared to wethers not supplemented with a loose mineral lick. In a study conducted by Doyle et al. (1988), they found that cows supplemented with zinc, copper, and manganese, added to a supplemental grain mix containing phosphorus, decreased the average length of time from the beginning of breeding season to conception ( 22 days compared to 42 days for non-supplemented cows). They also found that cows receiving trace mineral supplements had higher conception rates than a control group with no added trace elements.

Research conducted by Manspeaker et al. (1987) determined that the nutritional and mineral status at the cellular level is vital to endometrial pathology, embryonic viability and fertility. Boland et al. (2005) offered 39 ewes $48 \mathrm{~g}$ of a mineral/vitamin supplement containing $6.5 \mathrm{~g}$ of Ca, $4.9 \mathrm{~g}$ of $\mathrm{P}, 5.9 \mathrm{~g}$ of $\mathrm{Mg}, 4.0 \mathrm{~g}$ of $\mathrm{Na}, 790 \mathrm{mg}$ of $\mathrm{Zn}$, $3.5 \mathrm{mg}$ of Se, $40 \mathrm{mg}$ of I, $200 \mathrm{mg}$ of $\mathrm{Mn}, 20 \mathrm{mg}$ of Co, and $40 \mathrm{IU}$ of vitamin E. Boland et al. (2005) found that high mineral intakes in late pregnancy lowered serum IgG concentrations in the lamb, and resulted in the neonate being preprogrammed at birth so that it was born with a compromised ability to absorb colostral IgG. Boland et al. (2005) states that preliminary evidence from an ongoing study (Boland et al., 2004) suggests that the high iodine intake might be responsible for decreased IgG absorption. Iodine is a constituent of the thyroid hormones, which have been shown to affect the absorption of IgG in both the lamb and calf (Boland et al. 2005). 
Methods for Estimating Supplement

Intake by Grazing Animals

Determining individual supplement intake is necessary in evaluating mineral supplementation strategies. External markers are commonly used for measuring supplement intake by individual animals. External markers are indigestible materials that are either added to the diet, or administered intra-ruminally or orally to the animal (Pond et al., 1987). These markers are used to determine digestibility, fecal output, and other measures of forage utilization in grazing animals when total fecal collection is not practical (Kincheloe, 2004).

Chromic oxide is the most widely used external marker for the estimation of fecal output. Smith and Reid (1955) determined that fecal output can be estimated with about the same degree of accuracy regardless of whether $\mathrm{Cr}_{2} \mathrm{O}_{3}$ is administered in gelatin capsules or in a concentrate feed and whether it is administered once daily (0600 h) or twice daily (0600 and1600 h) by either means.

Hardison and Reid (1953) proposed that the bulking of equal weights of feces sampled at $0600 \mathrm{~h}$ and $1600 \mathrm{~h}$ during periods of seven or more days would provide samples of which the $\mathrm{Cr}_{2} \mathrm{O}_{3}$ concentration would allow accurate estimates of the total fecal output.

The research conducted by Smith and Reid (1955) also showed that the time of day (either morning or afternoon or both) when $\mathrm{Cr}_{2} \mathrm{O}_{3}$ is administered does not influence the accuracy with which the total output of feces may be derived from the $\mathrm{Cr}_{2} \mathrm{O}_{3}$ content of feces sampled at $0600 \mathrm{~h}$ and $1600 \mathrm{~h}$ They also found that sampling of feces at these 
times grants a recovery of approximately $100 \%$ of the ingested $\mathrm{Cr}_{2} \mathrm{O}_{3}$ and eliminates the need for a fecal-collection apparatus.

Glindemann et al. (2009) reported that titanium dioxide $\left(\mathrm{TiO}_{2}\right)$ is a reliable marker for estimating fecal excretion in grazing sheep. Titanium dioxide has been used as an alternative to chromic oxide and suitable results have been obtained in assays with

non-ruminants (Jagger et al., 1992; Short et al., 1996) and ruminant animals (Titgemeyer et al., 2001; Myers et al., 2006; Glindemann et al., 2009). The average fecal recovery of $\mathrm{Cr}_{2} \mathrm{O}_{3}$ and $\mathrm{TiO}_{2}$ was $99.50 \%$ and $101.95 \%$, respectively, in a study reported by Sampaio et al. (2011).

\section{$\underline{\text { Animal-Related Factors }}$}

$\underline{\text { Social Interactions }}$ Social interactions play an important role in supplement consumption by cattle and sheep. Dominant animals often consume large amounts of supplement and prevent other animals from consuming desired levels (McDowell, 2003). It may be possible to change dominance patterns by altering feeder design (Bowman and Sowell, 1997). However, inexperienced sheep commonly increase supplement intake in the presence of more experienced sheep (Foot et al., 1973).

Age Individual supplement intake variation usually decreases with time, as animals progress through the neophobic eating pattern found with unfamiliar supplements (Lobato and Pearce,1980a; Coombe and Mulholland, 1983). Two- and three-yr-old cows spent less time at the feeder and had fewer feeding bouts per day than 6-yr-old cows (Sowell et al., 2003). 
Taylor et al. (2002) used 120 ewes from 2 to 6 years of age in a study to compare intakes of pellet and block supplements. Among ewes consuming pellet supplement, 2year-olds consumed the least amount of supplement compared to all other age categories (avg. 71.3 vs. 119.9 g/d, respectively). For block-supplemented ewes, 2- and 3-year-olds consumed the least amount of supplement, with 4-, 5-, and 6-year-olds consuming the most supplement (avg. 31.5 vs. $74.9 \mathrm{~g} / \mathrm{d}$, respectively).

Wagnon (1965) examined the effect of social dominance on supplemental feeding in range cows aged 2 through 10 years. Results showed that when hand-feeding supplement in troughs, 2- and 3- year olds were driven away from the troughs by 4- to 10- year old cows before they were able to consume supplement. Variation in rank was also shown to affect intake of self-fed cottonseed meal by 4 - through 10 -year-old cows (Wagnon, 1965). Dominant older cows waited less time for an opportunity to eat and spent more time at the feeder than subordinate 4- and 5- year old cows. This resulted in less BW gain by the 4- and 5- year olds than the older cows (avg. $0.20 \mathrm{vs} .0 .33 \mathrm{~kg}$ gain/d, respectively). Barrows (1977) reported that mineral consumption tended to decline as cows increased in age.

Previous Experience Livestock exposed to new feeds often exhibit neophobia, or a cautious sampling or rejection of the feed that is not related to palatability (Launchbaugh, 1995). The acceptance and degree of preference by grazing animals for a specific supplement is likely to depend on recognition by the animal of the supplement as a potential foodstuff, prior experience of the animal with the same or similar 
supplements, social interactions and the degree of preference of the animal for the supplement relative to available forages (Provenza, 1996; Dixon et al., 2001).

An experiment was conducted to determine whether experience with molassesurea blocks prior to weaning would improve intake of blocks post-weaning in sheep (Lobato et al., 1980a). At two research locations, Lobato et al. (1980a) found that lambs previously offered blocks began consuming blocks immediately and increased intake rapidly, while lambs with no exposure to blocks did not consume supplement for the first week of study, after which intake was low and variable. Although other studies have reported large variability in intake of molasses-urea blocks (Lobato and Beilharz, 1979; Lobato and Pearce, 1980b), it appears that early exposure to blocks increases intakes at a later stage.

Individual Requirements Growth rate, number of offspring, and milk production influence mineral needs (McDowell, 2003). Added requirements of gestation and lactation increase mineral needs and, thereby, consumption. The higher the level of productivity, the more important an adequate level of mineral intake.

Individual vs. Group Feeding Researchers have investigated the effects of feeding animals individually as compared to a group-feeding situation. Kendall et al. (1983) compared individual supplement intake by ewes offered feed blocks and trough supplements fed competitively and feed blocks fed individually. Mean intakes of feed blocks for ewes in a competitive feeding situation averaged $0.40 \mathrm{~kg} / \mathrm{d}$, while mean intake of feed blocks for individually-fed ewes was nearly twice that at $0.73 \mathrm{~kg} / \mathrm{d}$. The authors 
expected that less dominant ewes would increase intake in a non-competitive situation and decrease overall intake variation. However, the average CV for supplement intake was slightly higher for individually-fed vs. group-fed ewes (42 vs. $40 \%$, respectively). The authors concluded that dominance-subordinate interactions did not play a major role in supplement intake variation. Foot and Russel (1973) designed an experiment to combine the effects of feeding situation with supplement allowance. Ewes were penned and fed individually, penned and fed in a group, or penned in a group and individually fed. Within each treatment, ewes were divided into two groups, one receiving a high level of supplement and the other a low level of supplement. Low supplement allowance ranged from 7 to $15 \mathrm{~g} / \mathrm{kg} \mathrm{BW}$ and high supplement allowance from 18 to $26 \mathrm{~g} / \mathrm{kg}$. Supplement intake CV's were both approximately $25 \%$ for sheep consuming either high or low levels of supplement and fed and penned in a group. Individually fed animals had CV's of $26 \%$ for ewes consuming a low level of supplement and $13 \%$ for ewes consuming a high level of supplement (Foot and Russel, 1973).

\section{$\underline{\text { Supplement-Related Factors }}$}

Supplement Form A variety of supplemental protein sources are available to producers, including oilseed by-products, soybeans and soybean meal, high quality hay, range cubes, blocks, and liquid supplements (DelCurto et al., 2000). The physical form of the supplement and the method by which it is delivered to the animal can influence variation in consumption (Bowman and Sowell, 1997). Supplement delivery methods are generally classified as self-fed or hand-fed systems. Hand-fed supplements generally 
include traditional dry supplements that are delivered to animals in specific amounts on a regular basis. Self-fed supplements are delivered in bulk amounts, and supplement is available for consumption on a free-choice basis (Sawyer and Mathis, 2001). Typically, feed blocks and liquid supplements are delivered in this way (Kincheloe, 2004). Liquid and block supplements, classified as self-fed, can be thought of as delivery methods that attempt to allow unlimited trough space per animal, and theoretically should increase an animal's opportunity to consume supplement, or reduce the percentage of non-feeders (Bowman and Sowell, 1997).

When grazing sheep were offered supplements of oats, chopped hay, or molassesurea blocks, CV of individual intake was $144 \%$ for blocks, $23 \%$ for oats, and $31 \%$ for hay (Lobato and Pearce, 1978; Lobato et al., 1980b). Eighteen percent of sheep did not consume any block supplement, but there were no non-feeders in the groups receiving oats or hay. Seven commercial flocks of grazing sheep were offered molasses-urea block supplements by Lobato and Pearce (1980a). After 3 weeks of supplementation, the proportion of non-feeders within a flock ranged from 21 to $100 \%$. Mean supplement intake by the flocks ranged from 0 to $31 \mathrm{~g} / \mathrm{d}$. Dove and Freer (1986) offered grazing lambs sunflower meal or pelleted sunflower meal supplements and found very little difference in the CV of individual supplement intake of meal $(21 \% \mathrm{CV})$ or pelleted supplement (18\% CV). Curtis et al. (1994) evaluated variation in supplement intake of a self-fed lupin seed supplement. When grazing Merino wethers were given an allowance of $600 \mathrm{~g} / \mathrm{d}$ lupin seed in a self-feeder, $33 \%$ of the sheep consumed less than $150 \mathrm{~g} / \mathrm{d}$, and $8 \%$ consumed over $1,200 \mathrm{~g} / \mathrm{d}$. Sixty-one percent of the wethers did not meet target 
consumption, and the CV of individual supplement intake was 83\%. Rocks et al. (1982) found that the intake of granulated salt by individual grazing sheep was consistently greater, and appeared more uniform, than the intake of the same material compressed into blocks.

Ducker et al. (1981) evaluated individual intake of supplement blocks by over 2,900 grazing ewes from 15 different flocks. Consumers of the supplement were marked when an apparatus applied paint to ewes' heads when they were consuming the supplement block. Overall, 19\% of ewes did not consume any block, and 36\% were classified as low consumers. The proportion of ewes in a flock that were non-feeders varied from 0 to $67 \%$. Intake $\mathrm{CV}$ also varied between flocks, ranging from 46 to $231 \%$, with a mean of $107 \%$. Grazing heifers offered cubed barley-SBM supplement in troughs had less individual variation in supplement intake (CV 31\%) than when the same quantity of DM was offered in molasses-urea blocks (CV 57\%; Kendall et al., 1980a). Individual supplement intake CV's were higher for grazing steers, but the trend for increased variation in intake with molasses-urea blocks (CV 82\%) compared with cubed barleySBM fed in troughs (CV 55\%) was similar.

Coombe and Mulholland (1983) found the CV of individual supplement intake by sheep grazing oat stubble to be $62 \%$ for molasses-based blocks, $66 \%$ for molasses-urea liquid supplement in a lick tank, and $86 \%$ for molasses delivered in a lick tank. Mean supplement intake as a percentage of the target supplement intake was $41 \%$ for blocks, $76 \%$ for molasses-urea liquid, and $80 \%$ for molasses. Over the 10 -week experimental period, target supplement intake was never achieved with the block supplement, whereas 
target consumption was reached by week 4 and 5 for molasses and molasses-urea liquid supplements. The total percentage of non-feeders was $2.5 \%$ for blocks, $22.5 \%$ for molasses-urea, and $30 \%$ for molasses. The percentage of non-feeders declined over the 10-week experimental period, and all sheep consumed some supplement on all treatments by the end of the 3 rd week. Although target consumption was not reached on the block supplement, the percentage of non-feeders was lower for the block than for the liquid supplements, especially during the first few weeks of supplementation.

Kendall et al. (1980b) offered sheep six different types of molasses-urea blocks. Metabolizable energy content $(0.81 \times$ digestible energy) of the feedblocks ranged from 7.9 to $9.2 \mathrm{MJ} / \mathrm{kg}$ dry matter. Average $\mathrm{CV}$ for individual intake of the blocks was $53 \%$, but the $\mathrm{CV}$ varied with block type, ranging from 35 to $63 \%$. Intake variation was greater for the blocks than when concentrates were fed in troughs. Even when less than $100 \mathrm{~g}$ of concentrate supplement was offered per ewe, more precise supplementation occurred with trough feeding than with blocks. Overall, Kendall et al. (1983) found that the CV for individual intake was higher with blocks (56\%) than with trough-fed concentrates (39\%) at equal average daily DM intakes. In this series of studies, a greater proportion of ewes supplemented with blocks had intakes below $100 \mathrm{~g}$ (11\% non-feeders) than of ewes receiving supplement in troughs ( $4 \%$ non-feeders).

$\underline{\text { Supplement Formulation }}$ Supplement characteristics such as hardness and nitrogen content may influence variation in consumption (Bowman and Sowell, 1997). Zhu et al. (1991) prepared supplement blocks based on liquid condensed solubles and dried distillers grain with solubles with a range of hardness indexes. Zhu et al. (1991) 
reported that supplement intake by cattle (measured by disappearance) decreased linearly as block hardness increased. Additionally, the CV of supplement intake increased as block hardness increased, averaging $17 \%$ for soft blocks, $23 \%$ for medium blocks, and $58 \%$ for hard blocks. Kendall et al. (1983) presented two molasses-urea block supplements varying in hardness to sheep. Individual intake CV was $29 \%$ for the block with softer consistency and $50 \%$ for the block with harder consistency.

Entwistle and Knights (1974) reported a greater proportion of non-feeders from Merino ewes grazing semi-arid tropical pastures when offered molasses alone compared with those offered urea in a liquid supplement with molasses. Lobato and Pearce (1980a) reported a lower percentage of non-feeders $(6.5 \%)$ when sheep were offered molassesurea blocks with three different formulations $(0,5$, and $10 \%$ urea) simultaneously compared with sheep offered only the 5\% urea blocks (12.3\%).

Ducker et al. (1981) offered molasses-urea blocks with 17, 20.5, and 24.3\% CP to grazing sheep. The CV for individual supplement intake and the percentage of nonfeeders decreased as the $\mathrm{CP}$ content of the blocks increased $(\mathrm{CV}=132,118$, and $82 \%$; non-feeders $=39,20$, and $13 \%$ for $17,20.5$, and $24.3 \% \mathrm{CP}$, respectively).

Ewes fed hay and housed in an open-fronted building were offered either barleySBM pellets or one of two molasses-urea block supplements (Kendall et al., 1983). Individual intake CV was $35 \%$ for the pellets, $29 \%$ for the high-intake block supplement (softer consistency), and 50\% for the low-intake block (harder consistency). When the same formulations as the block supplements were fed in meal form, the CV of individual supplement intake was $31 \%$. When grazing ewes were offered seven different types of 
molasses-urea block supplements varying in $\mathrm{CP}$ and energy content, the $\mathrm{CV}$ for intake ranged from 47 to $96 \%$, with an average intake $\mathrm{CV}$ of $68 \%$. Concentrate supplement fed in troughs to these grazing ewes was consumed with an average CV of $45 \%$ (Kendall et al., 1983).

Steers given access to medicated molasses blocks had CV's of individual supplement intake of $249 \%$ (Graham et al., 1977). Nine percent were non-feeders, and $27 \%$ consumed below the target amount. Nolan et al. (1974) found that $17 \%$ of pregnant heifers grazing native pasture did not consume measurable quantities of a molasses-urea liquid supplement.

A group of 200 ewes grazing poor-quality pasture was given access to a molassesurea liquid supplement in a float-lick dispenser, where a wax-impregnated wooden raft floated on top of the liquid supplement in an open trough (Nolan et al., 1975). This was intended to restrict consumption of the liquid supplement. Individual supplement intake, measured using tritiated water, indicated that the proportion of non-feeders was $49 \%$, and the $\mathrm{CV}$ for individual supplement intake was $52 \%$.

Mulholland and Coombe (1979) offered crossbred wethers grazing wheat crop residue access to molasses-based mineral or mineral-urea block supplements, or to molasses or molasses-urea liquid supplements in roller lick troughs. Mean supplement intake as a percentage of the target intake was $11 \%$ for the mineral block, $28 \%$ for the molasses-urea block, $55 \%$ for the molasses, and $37 \%$ for the molasses-urea liquid supplement. A total of five intake measurements were taken at 3-week intervals during the study. After the first 3 weeks, $8 \%$ of the animals on the mineral-urea block and $8 \%$ of 
the animals on the molasses lick supplement were non-feeders. After 6 weeks of the study, all animals consumed supplement. Coefficient of variation for individual supplement intake averaged $44 \%$ for the mineral block, $47 \%$ for the mineral-urea block, $64 \%$ for the molasses lick, and $58 \%$ for the molasses-urea lick.

Holst et al. (1994) offered lupin seed (grain) supplement to groups of 100 grazing wethers by either feeding it on the ground once daily or feeding it in a stationary feeder at the same rate $(600 \mathrm{~g} / \mathrm{d})$. The $\mathrm{CV}$ for individual supplement intake was $83 \%$ for the selffeeder and $47 \%$ for hand feeding on the ground. When supplement was self-fed, $27 \%$ of the animals were classified as non-feeders (consuming less than $100 \mathrm{~g} / \mathrm{d}$ ), whereas only $10 \%$ were non-feeders when the supplement was hand-fed. The mean intake was a greater percentage of the target intake when supplement was offered in the self-feeder $(84 \%)$ than when fed on the ground $(71 \%)$.

Supplement Allowance Larger quantities of supplement provided per animal reduce the variation in individual animal supplement consumption, and the proportion of non-feeders (Bowman and Sowell, 1997). Bowman and Sowell (1997) reported that greater supplement allowance does not necessarily result in a greater percentage of animals consuming the target amount. Foot et al. (1973) found CV's of concentrate supplement intake by ewes fed from troughs averaged 36\% when allowance was $100 \mathrm{~g} / \mathrm{d}$ and declined to $16 \%$ when allowance was $453 \mathrm{~g} / \mathrm{d}$. Ducker et al. (1981) reported that the proportion of grazing ewes not consuming block supplement was highest when average flock supplement consumption was low and decreased as average flock supplement consumption increased. 
Kahn (1994) fed cottonseed meal on the ground to grazing sheep at either 55 or $110 \mathrm{~g} / \mathrm{d}$. When the allowance was $55 \mathrm{~g} / \mathrm{d}, 30 \%$ of the flock consumed less than $10 \mathrm{~g} / \mathrm{d}$ supplement, whereas $20 \%$ of the flock offered $110 \mathrm{~g} / \mathrm{d}$ consumed less than $10 \mathrm{~g} / \mathrm{d}$. The proportion of non-feeders was lower with the higher supplement allowance, but little difference was observed in the percentage of sheep below target consumption (57 vs 53\% for 55 and $110 \mathrm{~g} / \mathrm{d}$ allowance). Kendall et al. (1980b) combined the effects of both trough space and supplement allowance by offering grazing ewes concentrate supplement at low (84 g/d), medium (252 g/d), and high (504 g/d) allowances, along with restricted (30 $\mathrm{cm} /$ animal), adequate (40 cm/animal), or generous $(53 \mathrm{~cm} /$ animal) trough space. When supplement allowance was high (504 g/d) trough space had little effect on CV of supplement intake $(27,38$, and $34 \%$ for 53,40 , and $30 \mathrm{~cm} /$ animal $)$; however, when supplement allowance was low $(84 \mathrm{~g} / \mathrm{d})$, trough space had a large effect on supplement intake CV (46, 58, and 74\% for 53, 40, and $30 \mathrm{~cm} /$ animal).

\section{Trough Space Changes in trough space per animal can influence} competitiveness and variation in supplement consumption (Arnold and Maller, 1974). Excess trough space can increase variation in hand-fed supplement consumption. Wagnon (1966) reported that with $91 \mathrm{~cm}$ of trough space per cow, less fighting and dominance/submissive behavior occurred during supplementation than when $180 \mathrm{~cm} / \mathrm{cow}$ was allowed. The proportion of sheep not consuming oat grain supplement fed once daily in troughs increased from 0 to $31 \%$ as trough space was decreased from 24 to 4 cm/animal (Arnold and Maller, 1974). 
$\underline{\text { Environmental Factors }}$

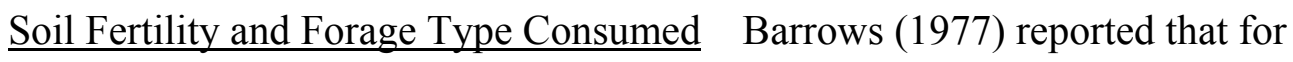
cattle, salt, calcium, phosphorus and magnesium each appeared to be consumed in relation to the content of the particular element in the grass.

Season of Year Season of the year affects mineral intake (Cunha, 1983), which is often greatest during the winter or dry season when forages stop growing, lose green color and become high in fiber and lignin and low in digestibility and mineral availability. As plants mature, mineral content declines (McDowell, 1985). Mineral supplement intake is lower when forage quality and quantity is optimal. Under drought conditions, mineral supplement intake is increased to counteract the low mineral availability in the forage and the low level of forage intake due to its reduced palatability (Cunha, 1983).

$\underline{\text { Available Energy-Protein Supplements }}$ The kind and level of protein-energy supplementation influences mineral supplement intake (McDowell, 2003). Protein and energy supplements that also provide minerals will decrease both the need and desire for free-choice minerals. Weber et al. (1992) reported a wide day-to-day variability in freechoice mineralized salt and protein block consumption by British-bred beef cows. Variation was much greater for salt-type blocks than for the softer, protein-type blocks, with several cows consuming none of the salt-type blocks for periods of several weeks. 


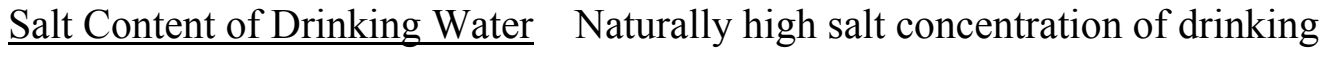
water decreases mineral supplement intake (McDowell, 2003). Livestock have a natural craving for salt. However, if that desire is fulfilled from drinking water high in salt, grazing livestock will consume less or none of a free-choice mineral mixture based on salt.

Palatability of Mineral Mixture In a review of salt appetite, Denton (1967) noted that all mammals have the ability to taste salt, and there is a universal liking for it. Becker et al. (1944) noted that the attitude of cattle toward salt in a mineral supplement is inversely related to the amount of salt present in feeds and water. Common salt, because of its palatability, is a valuable carrier of other minerals. If mixtures contain $30-40 \%$ salt or more, they are generally consumed on a free-choice basis in sufficient quantities to supply supplementary needs of other minerals (McDowell, 2003). Burghardi et al. (1982) concluded that the palatability of minerals and the hardness of supplement blocks were among the main factors accounting for differences in the amount consumed.

A review of the literature on variation in supplement intake in livestock presents an array of information. The variation in energy, protein and mineral supplement intake is attributable to animal-related factors, supplement-related factors, and environmental factors. Using the coefficient of variation (CV), the proportion of non-feeders, the proportion of animals consuming target supplement intake, and the proportion of animals over-consuming supplement, the variation in supplement intake can be compared across a wide assortment of studies. 


\section{MINERAL SUPPLEMENT INTAKE, FORAGE INTAKE, AND PERFORMANCE BY EWES}

\section{$\underline{\text { Summary }}$}

Sixty mature ewes (non-pregnant, non-lactating) were used in a completely randomized design to determine if feeding method of pea-barley forage (swath grazing or hay in confinement) had an effect on individual ewe salt/mineral mix consumption. Thirty ewes were randomly allocated to 3 confinement pens and 30 ewes were randomly allocated to 3 grazing plots. The study was conducted September 25 to October 15, 2010 and September 6 to 19, 2011. Targhee ewes $(65.4 \pm 5.84 \mathrm{~kg} \mathrm{BW})$ were used in 2010. Rambouillet ewes $(61.9 \pm 6.28 \mathrm{~kg} \mathrm{BW})$ were used in 2011 . Ewes had ad libitum access to food, water, and a mineral supplement containing 11 to $12.5 \%$ salt with $2 \% \mathrm{TiO}_{2}$ added as an external marker to estimate individual salt/mineral mix intake. On $\mathrm{d} 1$ of the data collection period, mineral/ $/ \mathrm{TiO}_{2}$ was weighed and placed in feeders in confinement pens and grazing plots. At the end of the collection period, remaining salt/mineral was weighed and consumed salt/mineral was recorded to provide an estimate of total salt/mineral intake via disappearance. Forage intake was calculated using estimates of fecal output obtained by dosing ewes with gelatin capsules containing $2 \mathrm{~g} \mathrm{Cr}_{2} \mathrm{O}_{3}$ daily for $14 \mathrm{~d}$, and in vitro 48-h DM indigestibility. Fecal grab samples were collected from each individual ewe for a period of $7 \mathrm{~d}$ and composited. Forage and salt/mineral intakes were analyzed using individual ewe as the experimental unit. A year $\times$ treatment interaction $(P$ $<0.01)$ existed for forage DMI and mineral DMI. Ewes in confinement consumed more 
forage than grazing ewes in 2010 (2.60 vs. $1.86 \mathrm{~kg} / \mathrm{d}$, respectively), but less than grazing ewes in 2011 (1.99 vs. $2.49 \mathrm{~kg} / \mathrm{d}$, respectively). Ewe ADG was greater $(P<0.01)$ in 2010 (average $0.23 \mathrm{~kg} \bullet \mathrm{ewe}^{-1} \cdot \mathrm{d}^{-1}$ ) than in $2011\left(\right.$ average $0.12 \mathrm{~kg} \bullet \mathrm{ewe}^{-1} \cdot \mathrm{d}^{-1}$ ) but did not differ $(P=0.26)$ between treatments. Mean salt/mineral intake was highest $(P<0.01)$ by grazing ewes in 2011 and 2010 (average $69 \mathrm{~g} / \mathrm{d}$ ), intermediate by ewes in confinement in $2010(57 \mathrm{~g} / \mathrm{d})$, and lowest by ewes in confinement in $2011(31 \mathrm{~g} / \mathrm{d})$. A year $\times$ treatment interaction $(P=0.05)$ existed for mineral DMI CV. Mineral DMI CV was higher $(P=$ 0.04) for the confinement treatment than the grazing treatment in 2011 (67.2 vs. 33.7\%), but similar for confinement and grazing treatments in 2010 (55.4 vs. 46.5\%, respectively). In this study, both swath grazing ewes and ewes in confinement consumed more salt/mineral than recommended by the mineral manufacturer and the NRC indicating that more research is needed to develop a better understanding of the factors that regulate and impact salt/mineral intake.

\section{$\underline{\text { Introduction }}$}

Since feed and supplement costs can be more than $50 \%$ of total operational costs for range livestock producers (USDA, 1994), monitoring supplement intake, and making sure animals receive the appropriate amount of nutrients, could reduce production costs. While researchers have looked at individual intake of protein and energy supplements, few studies have attempted to evaluate variation in individual consumption of salt/mineral mix supplements. There is a lack of information on the variation in salt/mineral intake, especially in sheep, and there is also an absence of information comparing swath-grazing sheep to sheep fed hay in confinement. 
The objective of this study was to determine if feeding method of pea-barley forage (swath grazing or hay in confinement) had an effect on individual ewe salt/mineral consumption. We hypothesized that individual salt/mineral mix supplement intake does not differ by ewes grazing or confinement-fed pea-barley forage.

\section{Materials and Methods}

\section{$\underline{\text { Sheep Selection and Management }}$}

All animal procedures were approved by the Montana State University Agricultural Animal Care and Use Committee (Protocol \#2009-AA04). Sixty mature ewes were selected from the Bair Ranch in Martinsdale, MT to be used in the first year of data collection. These ewes were chosen from a band of approximately 2,000 ewes from the Targhee flock owned by the Bair Ranch Foundation. The Targhee ewes (65.4 \pm 5.84 $\mathrm{kg} \mathrm{BW}$ ) chosen were non-pregnant and non-lactating. For the second year of data collection sixty mature Rambouillet ewes $(61.9 \pm 6.28 \mathrm{~kg} \mathrm{BW}$, non-pregnant, nonlactating) were selected from the Red Bluff Research Ranch near Norris in Madison County, MT. In 2010, ewes were transported from the Bair Ranch on September 25th to Montana State University's Fort Ellis Research Station in Bozeman, MT. The ewes arrived at approximately $1230 \mathrm{~h}$ after being held off of feed and water overnight. They were immediately paint branded for identification purposes and their shrunk weights were recorded. Beginning on September 25, 2010, ewes were randomly assigned to three grazing plots and three confinement pens (Figure 2). 
In 2011, ewes were transported from Red Bluff Research Ranch on September 6, 2011 to Montana State University's Fort Ellis Research Station in Bozeman, MT. The ewes arrived at approximately $1100 \mathrm{~h}$ after being held off of feed and water overnight. They were immediately paint branded for identification purposes and their shrunk weights were recorded. Beginning on September 6, 2011, ewes were randomly assigned to three grazing plots and three confinement pens. During 2010 and 2011 there were 10 ewes in each pen and plot and while in the plots and the pens sheep had ad libitum access to food, water and a salt/mineral mix supplement with $2 \% \mathrm{TiO}_{2}$ added as an external marker to estimate mineral intake.
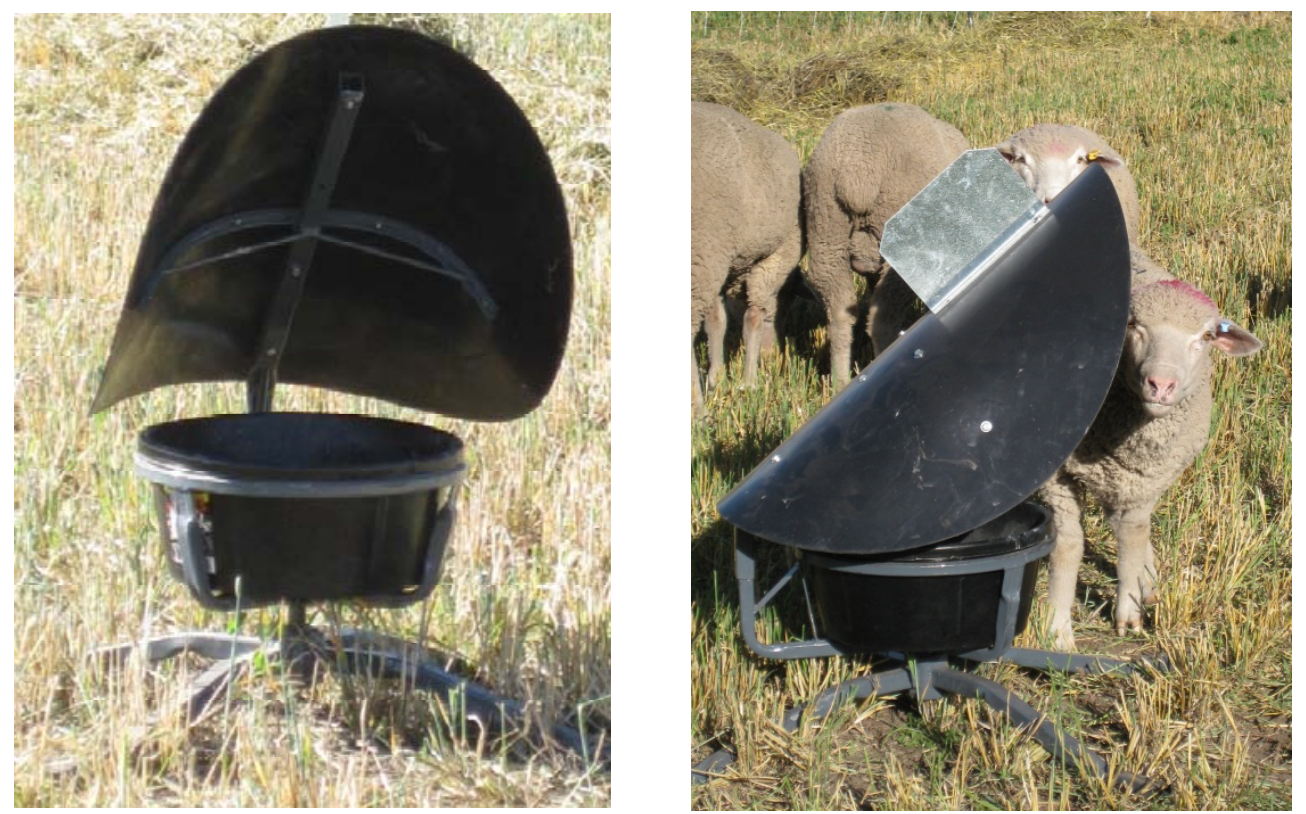

Figure 1. Photographs of the mineral feeders.

Mineral feeders were placed in confinement pens and grazed plots. There was 1 mineral feeder per 10 ewes. The feeders were raised off the ground and protected from rain, wind and contamination so the salt/mineral was not lost or wasted (Figure 1). 
During the adaptation period prior to data collection, sheep salt/mineral consumption was visually monitored on a daily basis. On $\mathrm{d} 1$ of the data collection period, all salt/mineral was removed from the feeder, weighed, and placed back in the feeder, along with an additional amount, to insure ad libitum consumption. At the end of the data collection period, the remaining salt/mineral mix was removed from the feeder, weighed, and salt/mineral disappearance was recorded.

For $7 \mathrm{~d}$ (September 25 to October 1, 2010 and September 6 to September 12, 2011) ewes in the grazing plots were restricted to half of a plot ( $0.07 \mathrm{ha}$ ) for an adaptation period (Figure 2), and ewes in confinement pens were fed their respective hay.

Throughout this week, the sheep in each plot and pen were moved into handling facilities and dosed with $\mathrm{Cr}_{2} \mathrm{O}_{3}$ as an external marker to estimate fecal output. Gelatin capsules filled with $2 \mathrm{~g}$ of $\mathrm{Cr}_{2} \mathrm{O}_{3}$ were administered with a balling gun between $1000 \mathrm{~h}$ and $1100 \mathrm{~h}$ every day as to avoid disturbing their major grazing periods. $\mathrm{The} \mathrm{Cr}_{2} \mathrm{O}_{3}$ reached equilibrium rate during the first week of dosing before fecal collection (Smith and Reid, 1955). Following the adaptation period, ewes were moved into the remaining half of a plot with fresh forage for the data collection period of $7 \mathrm{~d}$ (October 2 to October 8, 2010 and September 13 to 19, 2011) (Figure 2). During this data collection period, both sheep in plots and pens were gathered daily, dosed with $\mathrm{Cr}_{2} \mathrm{O}_{3}$, and fecal grab samples were collected from each individual animal between $1000 \mathrm{~h}$ and $1100 \mathrm{~h}$. Sheep in the confinement pens were moved into an adjacent handling facility for $\mathrm{Cr}_{2} \mathrm{O}_{3}$ dosing and fecal grab samples. 


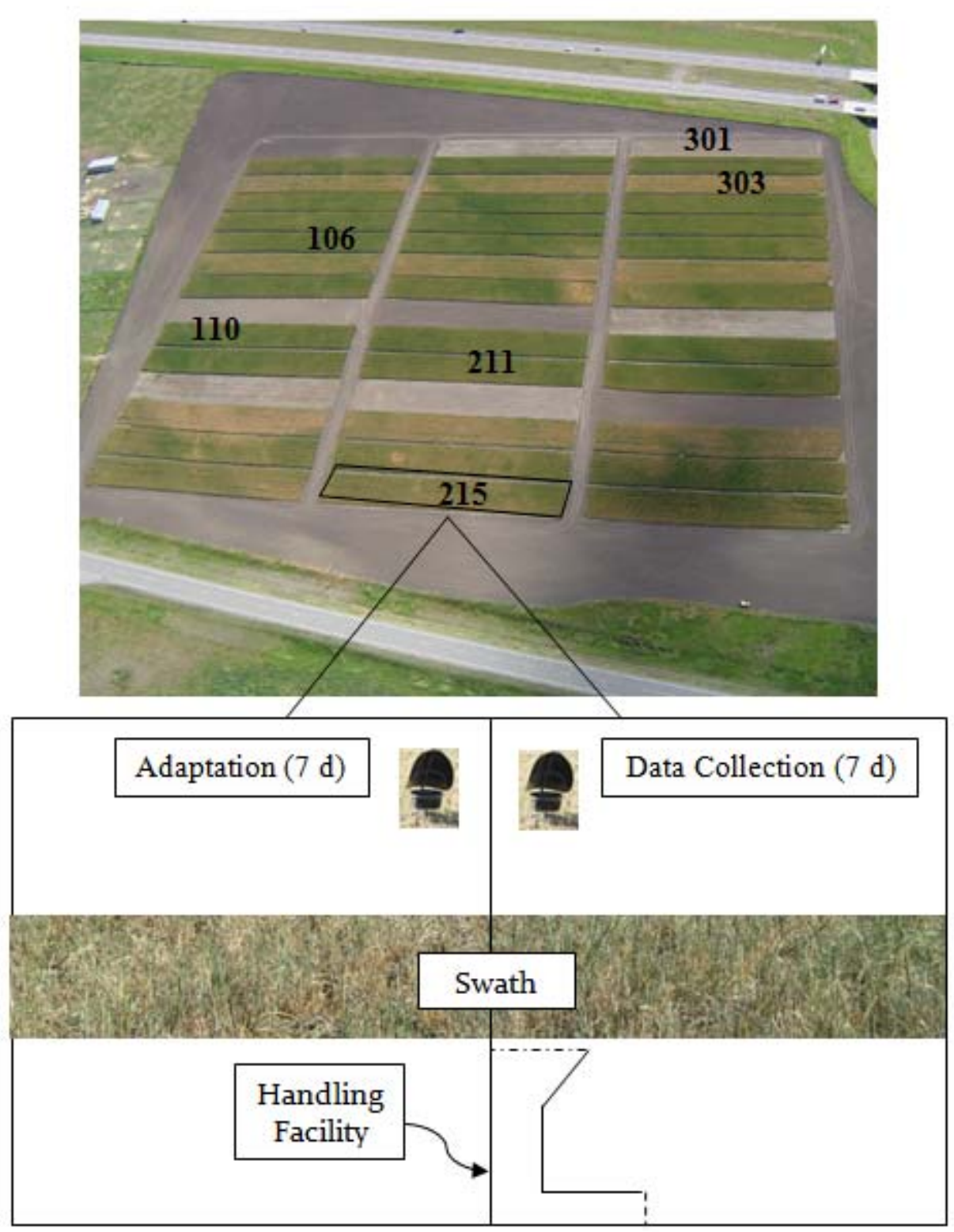

Figure 2. Aerial View of Fort Ellis Research Station with diagram of zoomed in individual plot area. 2010 grazing plots $=110,215$ and 303. 2011 grazing plots $=106$, 211, 301. 


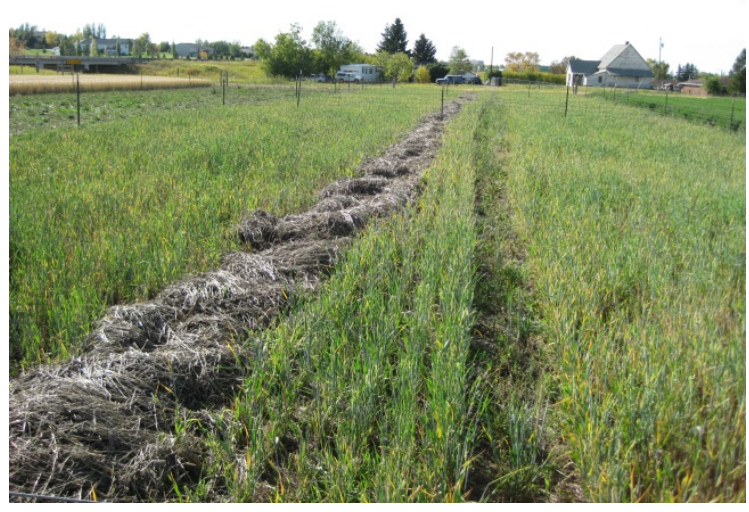

Figure 3. Photograph of one of the three swath-grazing plots before grazing.

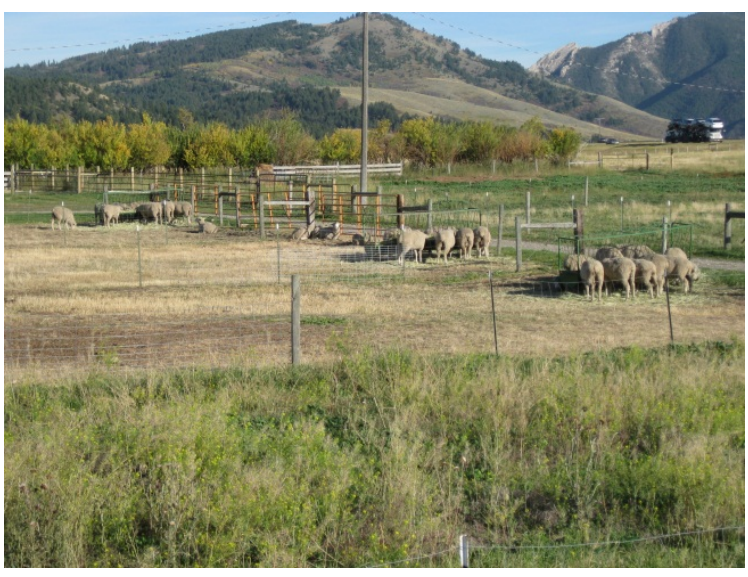

Figure 4. Photograph of the three confinement pens with sheep eating at hay feeders.

\section{Forage Disappearance}

To determine the amount of forage grazed, hand-clipped samples were collected prior to and after each grazing session. Samples were also collected from an un-grazed quadrant before and after a grazing week/session to determine disappearance not related to the sheep grazing and instead due to wind, wild animals, etc. Samples were collected with ten $0.1-\mathrm{m}^{2}$ rings randomly throughout the plot and three $10-\mathrm{cm}$ profile sections of the swath. Also, three, 1-m sections of windrow were weighed. These samples were used to calculate the disappearance by grazing. Baled hay intake was calculated by first taking the weight of the bales fed per day. Refused forage was gathered at the end of the data collection period and weighed.

\section{Forage Composition}

All forage samples were dried at $60^{\circ} \mathrm{C}$ and ground in a Wiley mill through a $1-\mathrm{mm}$ screen. Two $1-\mathrm{g}$ samples of the $1 \mathrm{~mm}$ forage were weighed, dried at $100^{\circ} \mathrm{C}$ for $24 \mathrm{~h}$, and 
reweighed to determine DM content. The DM content was used to calculate the forage availability on a DM basis. Forage samples were analyzed for N (AOAC, 2000) using a LECO machine, and NDF and ADF (Van Soest et al., 1991) as modified for use in an Ankom 200 fiber analyzer. Two 1-g samples of the 1-mm ground forage were weighed and placed in a muffle oven at $500^{\circ} \mathrm{C}$ for $15 \mathrm{~h}$ to determine ash weights for calculation of OM content (AOAC, 2000).

\section{$\underline{\text { Forage Digestibility and Forage Intake }}$}

Forage indigestibility was estimated using the in vitro technique from a modified Tilley and Terry (1963) method. Forage samples were weighed $(0.2500 \mathrm{~g})$ in triplicate into test tubes. Twenty milliliters of a pre-heated buffer solution was added to the samples and incubated at $39{ }^{\circ} \mathrm{C}$ for $20 \mathrm{~min}$. Rumen fluid was collected from two ruminally-cannulated cows, combined, and strained through 16 layers of cheese cloth. Five milliliters of rumen fluid were then added to the test tubes and sealed with rubber stoppers. Needles were placed through the rubber stoppers to allow the escape of gases. Test tubes were put into a $39^{\circ} \mathrm{C}$ oven for $48 \mathrm{~h}$. Test tubes were swirled at 2, 4, 20, 28 and $44 \mathrm{~h}$. After $48 \mathrm{~h}$, tubes were cold-shocked for $20 \mathrm{~min}$. Liquid was filtered from test tubes and particulate was collected on pre-weighed filter papers and allowed to dry in a $100^{\circ} \mathrm{C}$ oven for $48 \mathrm{~h}$. The dry filter papers were then weighed. The filter paper weights were subtracted from the combined filter paper/forage particulate weight to yield indigestible forage weight.

$\mathrm{Cr}_{2} \mathrm{O}_{3}$ was used as an external marker to measure intake in all sheep in the study. Sheep were dosed with chromic oxide at 24-h intervals for an adaptation period of $7 \mathrm{~d}$ 
and were continually dosed through the fecal collection period of $7 \mathrm{~d}$. Sheep were dosed orally using gelatin capsules containing $2 \mathrm{~g}$ of $\mathrm{Cr}_{2} \mathrm{O}_{3}$ administered with a balling gun. The chromic oxide reached equilibrium rate during the first week of dosing before fecal collection. Rectal grab samples were collected the second week of dosing while administering the $\mathrm{Cr}_{2} \mathrm{O}_{3}$ boluses (at $1000 \mathrm{~h}$ ). Chromium concentration was determined in rectal grab samples (Ellis et al., 1982). Fecal output (FO) was estimated using the following equation:

FO, $\mathrm{g} / \mathrm{d}=\mathrm{Cr}$ daily dose, $\mathrm{g} / \mathrm{d} \div$ Fecal $\mathrm{Cr}$ concentration, $\mathrm{g} / \mathrm{g}$

Forage dry matter intake was estimated using the following equation:

Forage DMI, $\mathrm{kg} / \mathrm{d}=\mathrm{FO}, \mathrm{kg} / \mathrm{d} \div$ forage indigestibility

$\mathrm{TiO}_{2}$ was added to the trace mineral/salt supplement as an external marker to estimate supplement intake. Cr concentration was used as a measurement of fecal output (forage intake) to aid in calculating ewe supplement intake. Fecal samples were analyzed for Ti content (Myers et al., 2004). Individual ewe supplement intake was estimated using the following equation:

Supplement intake $=($ fecal Ti, g/g $\times$ FO, g/d $) \div$ supplement Ti concentration, g/g

To determine the chromium content of the fecal samples, the samples were prepared by drying and then grinding to pass through a $1 \mathrm{~mm}$ screen. One gram of the dried, ground sample was weighed and added to a $45 \mathrm{~mL}$ silica basin. Sample was ashed at $600^{\circ} \mathrm{C}$ for $1 \frac{1 / 2}{2}$ hours, cooled and then $3 \mathrm{~mL}$ of phosphoric acid-manganese sulfate solution and $4 \mathrm{~mL}$ of potassium bromate solution was added. The sample was then covered with a watch-glass and digested on a previously heated hot plate until 
effervescence ceased and a purple color appeared (5-7 min). Again it was cooled, then diluted with water and washed completely into a $200 \mathrm{~mL}$ volumetric flask. Twenty-five milliliters of a calcium chloride solution containing 4,000 ppm calcium was added. It was brought to volume with water and mixed thoroughly. The sample was then allowed to stand overnight to allow the suspended material to settle or a portion was filtered. The final product was saved for analysis of chromium content by atomic absorption spectrometer at a later date.

A technique described by Myers et al. (2004) was used to determine the $\mathrm{Ti}$ content of the fecal samples. Fecal samples were dried and ground and then $0.5 \mathrm{~g}$ samples were weighed in duplicate into pre-weighed and acid-washed $250 \mathrm{~mL}$ macro-Kjeldahl digestion tubes. For each set of 20 tubes, 2 baseline samples of feces collected from an animal not fed $\mathrm{TiO}_{2}$ were included. One catalyst tablet was added to the tubes along with $13 \mathrm{~mL}$ of $\mathrm{H}_{2} \mathrm{SO}_{4}$. Tubes were then placed into a pre-heated Kjeldahl digestion block under a fume hood. An aspirator was placed onto the tubes and after $10 \mathrm{~min}$ the water pressure was reduced and samples were digested for $2 \mathrm{~h}$ at $420^{\circ} \mathrm{C}$. Tubes were then removed from heat and after $10 \mathrm{~min}$ the aspirator was removed. The tubes were cooled for $30 \mathrm{~min}$ before $10 \mathrm{~mL}$ of $30 \% \mathrm{H}_{2} \mathrm{O}_{2}$ was added to each sample. The samples were then allowed to cool for another $30 \mathrm{~min}$. Distilled water was added to each tube to bring the total volume of liquid up to $100 \mathrm{~mL}$. Tubes were then swirled and contents filtered to remove any precipitate. Samples were read on a UV/Vis spectrophotometer (2010) and an ICP machine (2011) at 410 nanometers. 
$\underline{\text { Mineral }}$

The salt/mineral fed in this study was Payback- Sheep Range Mineral 16-8 (Cenex Harvest States Inc., Montana) (Table 1). $\mathrm{TiO}_{2}$ was mechanically mixed into the salt $/$ mineral supplement at $2 \%$ of the total product to be used as an indigestible external marker. A $22.7 \mathrm{~kg}$ bag of mineral had $226.8 \mathrm{~g}$ of $\mathrm{TiO}_{2}$ mixed in. The target mineral intake was 7.09 to $14.17 \mathrm{~g} \bullet \mathrm{ewe}^{-1} \cdot \mathrm{d}^{-1}$ based on manufacturer recommendations. The mineral $/ \mathrm{TiO}_{2}$ mixture was available to the sheep throughout the duration of the study. Glindemann et al. (2009) reported that the equilibrium of intake and excretion of $\mathrm{TiO}_{2}$ was reached 5 days after initial $\mathrm{TiO}_{2}$ administration.

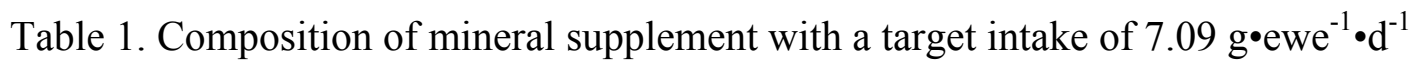
(values provided by manufacturer)

\begin{tabular}{lc}
\hline Item & Amount \\
\hline Calcium, min. & $12.0 \%$ \\
Calcium, max. & $14.0 \%$ \\
Phosphorus, min. & $12.0 \%$ \\
Salt, min. & $11.0 \%$ \\
Salt, max. & $12.5 \%$ \\
Magnesium, min. & $3.0 \%$ \\
Cobalt, min. & $4 \mathrm{ppm}$ \\
Copper, min. & $7 \mathrm{ppm}$ \\
Iodine, min. & $100 \mathrm{ppm}$ \\
Manganese, min. & $1,800 \mathrm{ppm}$ \\
Selenium, min. & $19.0 \mathrm{ppm}$ \\
Zinc, min. & $2,000 \mathrm{ppm}$ \\
Vit. A, min. & $250,000 \mathrm{IU} / \mathrm{lb}$ \\
Vit. D, min. & $25,000 \mathrm{IU} / \mathrm{lb}$ \\
Vit. E, min. & $500 \mathrm{IU} / \mathrm{lb}$ \\
\hline
\end{tabular}


$\underline{\text { Statistical Analyses }}$

Data was analyzed as a completely randomized design using the Proc GLM procedure of SAS (SAS Inst., Inc., Cary, NC). For all data (except the salt/mineral intake $\mathrm{CV}$ ), the experimental unit was individual ewe. For the mineral intake $\mathrm{CV}$ the experimental unit was pen or plot (a group of 10 ewes). Means were separated using the LSD procedure when a significant $\mathrm{F}$ value was found $(P \leq 0.05)$. Least square means and $P$-values are reported.

\section{$\underline{\text { Results and Discussion }}$}

\section{Forage Quality and Production}

Estimated forage production in 2011 was $19 \%$ higher $(1742.98 \mathrm{~kg} / \mathrm{ha})$ than forage production in 2010 (Table 2). Crude protein requirements for ewes at maintenance range from $104 \mathrm{~g}$ for $60 \mathrm{~kg} \mathrm{BW}$ to $113 \mathrm{~g}$ for $70 \mathrm{~kg} \mathrm{BW}$ ewes, respectively (NRC, 2007). Based on estimated DMI values, and CP concentration of the forage, all ewes met their CP protein requirements. Cunha (1983) reported that mineral supplement intake is lower when forage quality and quantity is optimal.

\section{Forage Intake and Ewe Performance}

Forage DMI $\left(P=0.40\right.$; average $\left.2.69 \mathrm{~kg} \bullet \mathrm{ewe}^{-1} \bullet \mathrm{d}^{-1}\right)$ and ADG $(P=0.26$; average $0.17 \mathrm{~kg} \bullet \mathrm{ewe}^{-1} \cdot \mathrm{d}^{-1}$ ) did not differ between treatments in either 2010 or 2011 . No year $\times$ treatment interactions $(P>0.04)$ were seen for ewe weight or ADG (Table 3). Treatment did not affect $(P>0.07)$ ewe weight or ADG, however, ewes were heavier $(P<0.01)$ and gained more weight $(P<0.01)$ in 2010 compared with 2011 (Table 3). There was a year 
$\times$ treatment interaction for forage intake $(P<0.01)$ and mineral supplement intake $(P=$ 0.01) (Table 3). In 2010, mean forage DMI was $2.23 \mathrm{~kg}$ vs. $2.24 \mathrm{~kg}$ in 2011. Mean forage intake (DMI \% BW) was 3.30 in 2010 vs. 3.59 in 2011. Mean mineral supplement intake (DMI) was $60.67 \mathrm{~g} / \mathrm{d}$ in 2010 vs. $51.87 \mathrm{~g} / \mathrm{d}$ in 2011. Cunha (1983) reported that under drought conditions, mineral supplement intake is increased to counteract the low mineral availability in the forage and the low level of forage intake due to its reduced palatability.

\section{Mineral Supplement Intake}

All individual fecal samples contained some level of $\mathrm{TiO}_{2}$, indicating that all ewes consumed some level of the salt/mineral supplement. Fecal $\mathrm{TiO}_{2}$ concentrations from ewe samples overestimated individual salt/mineral supplement intake so that total intake for each treatment was more than what was actually fed based on disappearance measurements. Therefore, individual salt/mineral supplement intakes were adjusted based on disappearance. The following calculations show how the 2010 correction factor was calculated for use in the adjustment of 2010 mineral intake values:

Total calculated mineral intake (Ti determination in fecal samples) for all ewes in confinement and pasture treatments $=33,545 \mathrm{~g} / \mathrm{wk}$

Total observed mineral intake (disappearance measurements) for all ewes in confinement and pasture treatments $=26,073 \mathrm{~g} / \mathrm{wk}$

$$
26,073 \div 33,545=0.78
$$

The correction factor we used to multiply the individual ewe intakes by to adjust for over estimation in 2010 was 0.78 . 
The following calculations show how the 2010 correction factor was calculated for use in the adjustment of 2011 mineral intake values:

Total calculated mineral intake (Ti determination in fecal samples) for all ewes in confinement and pasture treatments $=23,635 \mathrm{~g} / \mathrm{wk}$

Total observed mineral intake (disappearance measurements) for all ewes in confinement and pasture treatments $=21,371 \mathrm{~g} / \mathrm{wk}$

$$
21,371 \div 23,635=0.90
$$

The correction factor we used to multiply the individual ewe intakes by to adjust for over estimation in 2011 was 0.90 .

Mean mineral supplement intake was higher $(P<0.01)$ for ewes in the pasture treatment vs. ewes in the confinement treatment for 2010 and 2011 (64.21 vs. 57.12, and 73.05 vs. $30.68 \mathrm{~g} \bullet e w \mathrm{e}^{-1} \cdot \mathrm{d}^{-1}$, respectively; Table 3 ). There was a year $\times$ treatment interaction for mean supplement DMI ( $P=0.02$; Table 3). On average, ewes in 2010 consumed more mineral than ewes in 2011 (60.33 vs. $51.85 \mathrm{~g} \bullet \mathrm{ewe}^{-1} \bullet \mathrm{d}^{-1}$, respectively; Figure 5). In 2010, 98\% of ewes consumed over the target mineral intake of $7.09 \mathrm{~g} \bullet \mathrm{ewe}^{-}$ ${ }^{1} \cdot \mathrm{d}^{-1}$. In 2011, 100\% of ewes consumed over the target amount (Figure 5) resulting in mineral intakes higher than requirements.

Mean mineral intake was highest $(P<0.01)$ by grazing ewes in 2010 and 2011 (average $69 \mathrm{~g} / \mathrm{d}$ ), intermediate by ewes in confinement in 2010 (57 g/d), and lowest by ewes in confinement in 2011 (31 g/d) (Figure 5). The increased consumption of mineral by swath-grazing ewes could be due to the small area of the grazing plots. While grazing plots measured 0.14 ha, ewes were only in half of a plot (0.07 ha) during the data 
collection period. Ewes swath-grazing on 0.07 ha may have traveled past the mineral feeders more often while grazing, therefore possibly consuming more mineral than ewes in confinement. Confinement pens measured 0.05 ha but hay was fed in the same designated areas every day reducing the amount of travel past mineral feeders by ewes. It was also observed that ewes in confinement spent the majority of the day gathered around the hay feeders eating, resting, or ruminating.

2010

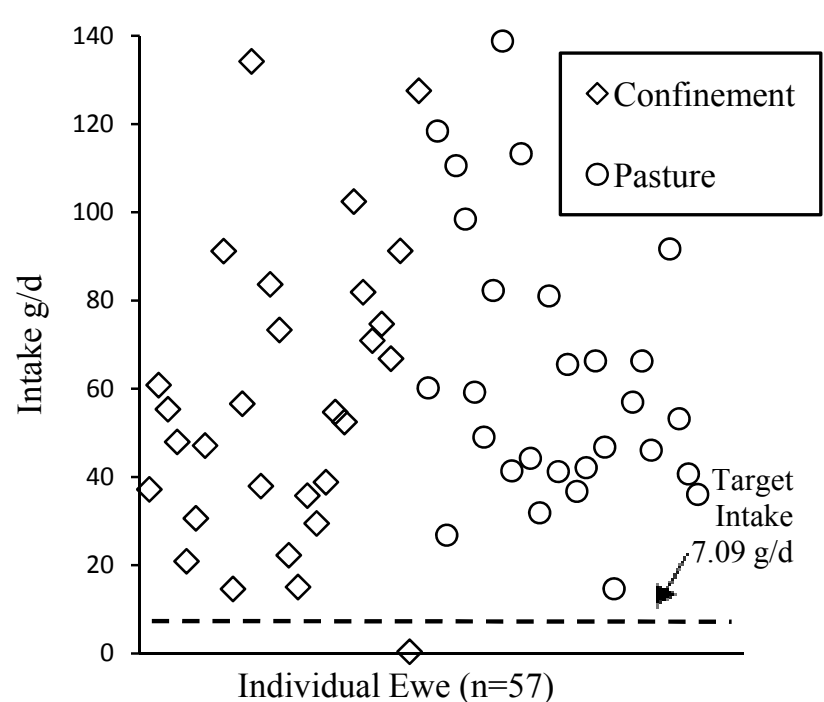

2011

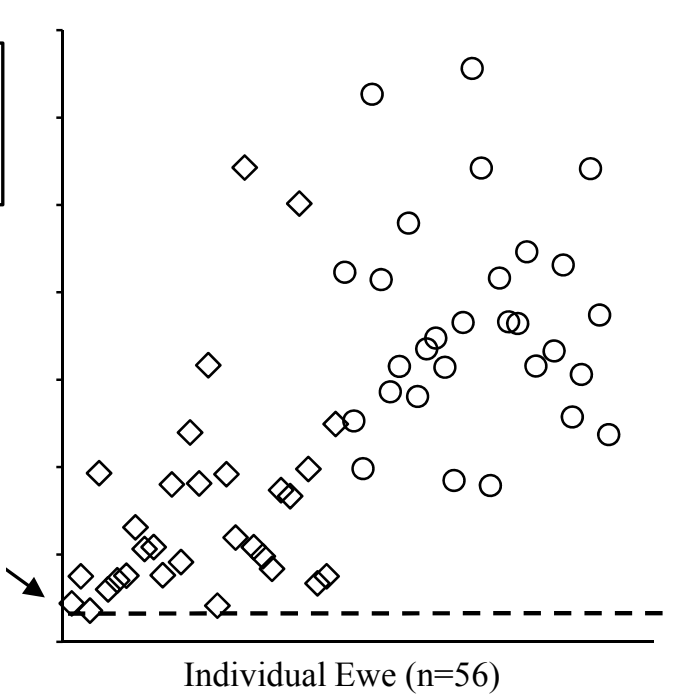

Figure 5. Individual ewe mineral intake (g/d) in 2010 and 2011. Target mineral intake was $7.09 \mathrm{~g} / \mathrm{d}$.

In this study, both swath grazing ewes and ewes in confinement consumed more mineral than recommended by the mineral manufacturer and the NRC. This indicates that more research is needed to develop a better understanding of the factors that regulate and impact mineral intake. 


\section{Distribution of Mineral Supplement Intake}

Ewes visited the mineral feeders most often during the afternoon between grazing bouts. A small group of ewes (usually 2 to 4 ) would gather around the feeder and wait while each ewe consumed some mineral. Denton and Sabine (1963) reported that the sight and sound of another animal drinking a Na solution often would excite a large increase of salivary secretion rate in a depleted sheep. On some occasions it was observed that the act of drinking a Na solution by an excited depleted sheep caused an apparently satiated sheep in normal $\mathrm{Na}+$ balance to return its attention to the $\mathrm{Na}$ solution container and drink some (Denton and Sabine, 1963).

Mineral supplement DMI CV was higher $(P=0.04)$ for the confinement treatment in year 2010 and 2011 (55.42 vs. 46.50 and 67.18 vs. $33.65 \%)$. There was a year $\times$ treatment interaction for supplement DMI CV $(P=0.05$; Table 3$)$. The mean DMI CV in 2010 was $50.96 \%$ compared to $50.42 \%$ in 2011 .

In 2010, prior to the study, the ewes from the Bair Ranch had access to a 50\% salt/mineral mix for 2 weeks before breeding and for 2 weeks during lambing. The ewes from the Red Bluff Research Ranch, used for the second year of the study in 2011, had year-round, ad libitum access to a mineral mix with 50\% salt added. It has been reported that competition between animals for supplement may increase variation in intake (Arnold and Maller, 1974). Bair Ranch ewes were allowed access to a mineral mix only 4 weeks out of the year prior to the study. Their previous experience with this 4 week supplementation program may have led them to compete for mineral during our study 
and therefore consume greater amounts than the Red Bluff Research Ranch ewes that had year-round access to a mineral mix. 


\section{SUMMARY AND IMPLICATIONS}

There is no literature on individual mineral intake in sheep and no literature on variation in sheep mineral intake. This research adds to the literature and body of knowledge. It is also biological research that becomes the foundation for economic evaluation and will aid feed companies in formulating mineral rations that meet sheep requirements. In this study, both swath grazing ewes and ewes in confinement consumed more salt/mineral than recommended by the mineral manufacturer and the NRC. More research is needed to develop a better understanding of the factors that regulate and impact mineral intake so the appetite of over-eaters can be curbed reducing mineral costs for producers. Ewes in 2010 may have been salt-deprived prior to the study encouraging them to over-consume the mineral mixture. 
Table 2. Production and composition of pea-barley forage consumed byewes fed in confinement pens or grazing plots (based on clipped samples)

\begin{tabular}{|c|c|c|c|c|c|c|c|c|c|c|c|c|}
\hline \multirow[b]{3}{*}{ Location } & \multicolumn{5}{|c|}{2010} & \multicolumn{7}{|c|}{2011} \\
\hline & \multicolumn{3}{|c|}{ Confinement } & \multicolumn{3}{|c|}{ Pasture } & \multicolumn{3}{|c|}{ Confinement } & \multicolumn{3}{|c|}{ Pasture } \\
\hline & $1^{1}$ & $2^{2}$ & $3^{3}$ & 110 & 215 & 303 & $1^{4}$ & $2^{5}$ & $3^{6}$ & 106 & 211 & 301 \\
\hline Sampling date & $10 / 7 / 10$ & $10 / 7 / 10$ & $10 / 7 / 10$ & $10 / 7 / 10$ & $10 / 7 / 10$ & $10 / 7 / 10$ & $8 / 22 / 11$ & $8 / 22 / 11$ & $8 / 22 / 11$ & $8 / 22 / 11$ & $8 / 22 / 11$ & $8 / 22 / 11$ \\
\hline Size of pasture, ha & 0.14 & 0.14 & 0.14 & 0.14 & 0.14 & 0.14 & 0.14 & 0.14 & 0.14 & 0.14 & 0.14 & 0.14 \\
\hline Production, kg/ha & 3815.04 & 4008.28 & 3307.00 & 3833.82 & 3205.52 & 3433.97 & 5820.34 & 3928.70 & 3343.18 & 4345.90 & 5310.87 & 4083.52 \\
\hline \multicolumn{13}{|l|}{ Composition, $\%$} \\
\hline $\mathrm{DM}$ & 93.07 & 93.56 & 93.01 & 93.56 & 93.33 & 93.77 & 94.56 & 92.93 & 92.71 & 90.80 & 90.43 & 92.63 \\
\hline $\mathrm{OM}$ & 92.73 & 92.68 & 92.79 & 92.54 & 91.92 & 91.26 & 92.30 & 91.53 & 92.46 & 92.50 & 92.92 & 90.77 \\
\hline $\mathrm{CP}$ & 10.45 & 10.79 & 10.26 & 10.79 & 9.90 & 13.14 & 7.80 & 6.65 & 6.97 & 6.93 & 7.84 & 7.01 \\
\hline $\mathrm{NDF}$ & 50.68 & 54.72 & 47.02 & 57.95 & 51.30 & 55.71 & 45.32 & 50.79 & 49.98 & 53.54 & 47.95 & 50.42 \\
\hline $\mathrm{ADF}$ & 28.10 & 29.36 & 28.72 & 30.41 & 28.35 & 29.72 & 23.71 & 27.84 & 28.15 & 28.26 & 25.76 & 27.34 \\
\hline \multicolumn{13}{|l|}{$\begin{array}{c}\text { DM } \\
\text { Disappearance, } \%\end{array}$} \\
\hline Baled & 57.38 & 57.38 & 57.38 & - & - & - & 48.20 & 48.20 & 48.20 & - & - & - \\
\hline Regrowth & - & - & - & 56.30 & 56.30 & 56.30 & - & - & - & 34.63 & 34.63 & 34.63 \\
\hline Swath & - & - & - & 34.06 & 34.06 & 34.06 & - & - & - & 37.32 & 37.32 & 37.32 \\
\hline \multicolumn{13}{|l|}{ DOM:CP } \\
\hline Baled & 5.09 & 4.93 & 5.19 & - & - & - & 5.70 & 6.63 & 6.40 & - & - & - \\
\hline Regrowth & - & - & - & 4.83 & 5.23 & 3.91 & - & - & - & 4.62 & 4.10 & 4.48 \\
\hline Swath & - & - & - & 2.92 & 3.16 & 2.37 & - & - & - & 4.98 & 4.42 & 4.83 \\
\hline
\end{tabular}

${ }^{1}$ Ewes in Confinement Pen 1 were fed baled hay from Plot 115

${ }^{2}$ Ewes in Confinement Pen 2 were fed baled hay from Plot 203

${ }^{3}$ Ewes in Confinement Pen 3 were fed baled hay from Plot 310

${ }^{4}$ Ewes in Confinement Pen 1 were fed baled hay from Plot 101

${ }^{5}$ Ewes in Confinement Pen 2 were fed baled hay from Plot 201

${ }^{6}$ Ewes in Confinement Pen 3 were fed baled hay from Plot 306 
Table 3. Performance, forage dry matter intake, and mineral supplement intake by ewes consuming pea-barley forage in confinement pens or swath grazing plots

\begin{tabular}{|c|c|c|c|c|c|c|c|c|}
\hline \multirow[b]{3}{*}{ Item } & \multicolumn{2}{|c|}{2010} & \multicolumn{2}{|l|}{2011} & \multirow[b]{3}{*}{ SE } & \multirow{2}{*}{\multicolumn{3}{|c|}{$P$ value }} \\
\hline & \multicolumn{4}{|c|}{ Treatment } & & & & \\
\hline & Confinement & Pasture & Confinement & Pasture & & Year & Trt & Year*Tr \\
\hline No. of ewes & 28 & 28 & 29 & 28 & - & - & - & - \\
\hline \multicolumn{9}{|l|}{ Weight, kg } \\
\hline Initial & 64.74 & 66.23 & 60.76 & 63.22 & 1.09 & 0.02 & 0.07 & 0.66 \\
\hline Ending & 71.29 & 71.82 & 62.49 & 64.70 & 1.08 & $<0.01$ & 0.21 & 0.44 \\
\hline Wt change & 6.55 & 5.59 & 1.73 & 1.49 & 0.46 & $<0.01$ & 0.20 & 0.43 \\
\hline $\mathrm{ADG}, \mathrm{kg}$ & 0.24 & 0.21 & 0.12 & 0.11 & 0.02 & $<0.01$ & 0.26 & 0.70 \\
\hline \multicolumn{9}{|l|}{ Forage intake } \\
\hline $\mathrm{DM}, \mathrm{kg}$ & $2.60^{\mathrm{b}}$ & $1.86^{\mathrm{a}}$ & $1.99^{\mathrm{a}}$ & $2.49^{\mathrm{b}}$ & 0.14 & 0.96 & 0.40 & $<0.01$ \\
\hline $\mathrm{DM}, \% \mathrm{BW}$ & $3.88^{\mathrm{b}}$ & $2.71^{\mathrm{a}}$ & $3.25^{\mathrm{a}}$ & $3.93^{\mathrm{b}}$ & 0.23 & 0.21 & 0.30 & 0.01 \\
\hline \multicolumn{9}{|c|}{ Mineral-supplement intake } \\
\hline Mean DMI g/d & $57.12^{b}$ & $64.21^{\mathrm{bc}}$ & $30.68^{\mathrm{a}}$ & $73.05^{\mathrm{c}}$ & 5.24 & 0.10 & $<0.01$ & 0.01 \\
\hline
\end{tabular}

a-cMeans within a row with different superscripts differ $(P<0.05)$ 
Table 4. Mineral-supplement intake distribution by ewes consuming pea-barley forage in confinement pens or swath grazing plots

\begin{tabular}{|c|c|c|c|c|c|c|c|c|}
\hline \multirow[b]{3}{*}{ Item } & \multicolumn{3}{|c|}{2010} & \multicolumn{2}{|l|}{011} & & & \\
\hline & & Treat & $\operatorname{ment}^{\mathrm{a}}$ & & \multirow[b]{2}{*}{ SE } & \multicolumn{3}{|c|}{$P$-value } \\
\hline & Confinement & Pasture & Confinement & Pasture & & Year & Trt & Year*Trt \\
\hline \multicolumn{9}{|l|}{ Supplement DMI, g } \\
\hline Min. & 10.03 & 24.46 & 9.61 & 40.96 & 4.0 & 0.08 & 0.05 & 0.07 \\
\hline Max. & 117.66 & 118.00 & 82.51 & 121.65 & 14.4 & 0.31 & 0.21 & 0.22 \\
\hline Mean & $56.70^{\mathrm{b}}$ & $63.95^{\mathrm{b}}$ & $30.68^{\mathrm{a}}$ & $73.02^{b}$ & 6.4 & 0.22 & 0.05 & 0.02 \\
\hline Supplement DMI CV, \% & $55.42^{\mathrm{bc}}$ & $46.50^{\mathrm{ab}}$ & $67.18^{\mathrm{c}}$ & $33.65^{\mathrm{a}}$ & 5.3 & 0.92 & 0.04 & 0.05 \\
\hline
\end{tabular}

${ }^{a}$ Experimental unit was either confinement or pasture

a-cMeans within a row with different superscripts differ $(P<0.05)$ 


\section{LITERATURE CITED}

Allden, W. G. 1987. Energy and Protein supplements for grazing livestock. In: J. B. Hacker and J. H. Ternouth (Ed.) The Nutrition of Herbivores. p. 289-307.

AOAC, 2000. Official Methods of Analysis (17 ${ }^{\text {th }}$ Ed.). J AOAC Int ISSN: 1060-3271. Arlington, VA.

Arnold, G. W., and R. A. Maller. 1974. Some aspects of competition between sheep for supplementary feed. Anim. Prod. 19:309-319.

Barrows, G. T. 1977. Research efforts have lagged in free-choice feeding. Anim. Nutr. Hlth. May 12- 14.

Becker, R. B., G. K. Davis, W. G. Kirk, R. S. Glasscock, A. P. T. Dix, and J. E. Pace. 1944. Defluorinated superphosphate for livestock. Bull. 401, Fla. Agric. Exp. Stn., Gainesville, FL.

Boland, T. M., M. J. Guinan, M. A. Foley, P. J. Quinn, J. J. Callan, and T. F. Crosby. 2004. The effect of iodine supplementation to ewes in late pregnancy on lamb serum immunoglobulin level. J. Anim. Sci. 82(Suppl. 1):31. (Abstr.)

Boland, T. M., N. Keane, P. Nowakowski, P. O. Brophy, and T. F. Crosby. 2005. High mineral and vitamin $\mathrm{E}$ intake by pregnant ewes lowers colostral immunoglobulin G absorption by the lamb. J. Anim. Sci. 2005. 83:871-878.

Bowman, J. G. P., and B. F. Sowell. 1997. Delivery method and supplement consumption by grazing ruminants: A review. J. Anim. Sci. 75:543-550.

Burghhardi, S. R., R. D. Goodrich, J. C. Meiske, M. L. Thonney, D. H. Theuninck, T. S. Kahlon, D. E. Pamp, and K. Kraiem. 1982. Free choice consumption of minerals by lambs fed calcium-adequate or calcium-deficientdiets. J. Anim. Sci., 54: 410418.

Cockwill, C. L., T. A. McAllister, M. E. Olson, D. N. Milligan, B. J. Ralston, C. Huisma, and R. K. Hand. 2000. Individual intake of mineral and molasses supplements by cows, heifers and calves. Can. J. Anim. Sci. 80: 681-690.

Coombe, J. B., and J. G. Mulholland. 1983. Utilization of urea and molasses supplements by sheep grazing oat stubble. Aust. J. Agric. Res. 34:767-780.

Cunha, T. J. 1983. Feedstuffs 55(41):39.

Curtis, K.M.S., P. J. Holst, and P. J. Murray. 1994. Measuring supplement intake in the field using Ytterbium. Aust. J. Exp. Agric. 34:339-343. 
DelCurto, T., B. W. Hess, J. E. Huston, and K. C. Olson. 2000. Optimum supplementation strategies for beef cattle consuming low-quality roughages in the western United States. Proc. Am. Soc. Anim. Sci., 1999.

Denton, D.A. 1967. Salt appetite.Handbook of Physiology I. Am. Physiological Society, Washington, DC.

Denton, D. A., and J. R. Sabine. 1963. The behavior of Na deficient sheep. Behaviour 20:364-376.

Distel, R. A., J. J. Villalba, and H. E. Laborde. 1994. Effects of early experience on voluntary intake of low-quality roughage by sheep. J. Anim. Sci. 72:1191-1195.

Dixon, R. M., D. R. Smith, I. Porch, and J. C. Petherick. 2001. Effects of experience on voluntary intake of supplements by cattle. Aust. J. Exp. Agric. 41:581-592.

Dove, H., and M. Freer. 1986. The use of tritiated gypsum for estimating individual intakes of pelleted or unpelleted supplement by lambs fed individually or in groups. Aust. J. Exp. Agric. 26:19-22.

Ducker, M. J., P. T. Kendall, R. G. Hemingway, and T. H. McClelland. 1981. An evaluation of feedblocks as a means of providing supplementary nutrients to ewes grazing upland/hill pastures. Anim. Prod. 33:51-57.

Ellis, W. C., J. H. Marls, K. R. Pond, C. Lascano, and J. P. Telford. 1984. Dietary influences on flow rate and digestive capacity. In: F.M.S. Gilchrist and R. I. Mackie (Ed.) Herbivore Nutrition in the Sub-tropics and Tropics. pp 269-293. The Science Press, Johannesburg.

Entwistle, K. W., and G. Knights. 1974. The use of urea-molasses supplements for sheep grazing semi-arid tropical pastures. Aust. J. Exp. Agric. Anim. Husb. 14:17-22.

Foot, J. Z., and A.J.F. Russel. 1973. Some nutritional implications of group-feeding hill sheep. Anim. Prod. 16:293-302.

Foot, J. Z., A.J.F. Russel, T. J. Maxwell, and P. Morris. 1973. Variation in intake among group-fed pregnant Scottish Blackface ewes given restricted amount of food. Anim. Prod. 17:169-177.

Glindemann, T., B. M. Tas, C. Wang, S. Alvers, and A. Susenbeth. 2009. Evaluation of titanium dioxide as an inert marker for estimating faecal excretion in grazing sheep. Anim. Feed Sci. Tech. 152:3:186-197. 
Graham, C. A., C. Pern, and K. L. Linehan. 1977. Individual daily consumption of a medicated bloat block. Aust. J. Exp. Agric. Anim. Husb. 17:562-565.

Greene, L. W. 2000. Designing mineral supplementation of forage programs for beef cattle. J. Anim. Sci. 77:1-9.

Hardison, W. A., and J. T. Reid. 1953. Use of indicators in the measurements of the dry matter intake of grazing animals. J. Nutrition, 51:35-52.

Holst, P. J., K.M.S. Curtis, and D. G. Hall. 1994. Methods of feeding grain supplements and measuring their intake by adult sheep. Aust. J. Exp. Agric. 34:345-348.

Jagger, S., J. Wiseman, and D. J. A. Cole. 1992. Evaluation of inert markers for the determination of ileal and fecal apparent digestibility values in the pig. British Journal of Nutrition, 68:729-739.

Kahn, L. P. 1994. The use of lithium chloride for estimating supplement intake in grazing sheep: Estimates of heritability and repeatability. Aust. J. Agric. Res. 45:17311739.

Kendall, P. T., M. J. Ducker, and R. G. Hemingway. 1980a. Individual intake variation by cattle given self-help feed blocks or cubed concentrate fed in troughs. Anim. Prod. 30:485.

Kendall, P. T., M. J. Ducker, and R. G. Hemingway. 1983a. Individual intake variation in ewes given feedblock or trough supplements indoors or at winter grazing. Anim. Prod. 36:7-19.

Kendall, P. T., R. G. Hemingway, and M. J. Ducker. 1980b. Variation in probable feed intake of ewes given concentrates with varying trough space allowance or selfhelp feedblocks. Proc. Nutr. Soc. 30:16A.

Kincheloe, J. J. 2004. Variation in Supplement Intake by Grazing Beef Cows [Master's Thesis]. Bozeman, MT: Montana State University.

Kott, R. "Nutrition - MT Sheep Production Handbook." Extension Service — Animal \& Range Sciences. 2005. Web accessed: 13 Sept. 2010.

$<$ http://www.animalrangeextension.montana.edu/articles/sheep/FlockHandbook/N utrition-1.htm>.

Launchbaugh, K. L. 1995. Effects of neophobia and aversions on feed intake: Why feedlot cattle sometimes refuse to eat nutritious feed. In: Symposium Intake by Feedlot Cattle. Okla. Agric. Exp. Sta. P-942. Page.36-48. 
Lobato, J. F., and G. R. Pearce. 1978. Variability in the intake of supplements by grazing sheep. Proc. Aust. Soc. Anim. Prod. 12:164.

Lobato, J.F.P., and R. G. Beilharz. 1979. Relation of social dominance and body size to intake of supplements in grazing sheep. Appl. Anim. Ethol. 5:233-239.

Lobato, J.F.P., and G. R. Pearce.1980a.Responses to molasses-urea blocks of grazing sheep and sheep in yards. Aust. J. Exp. Agric. Anim. Husb. 20:417-421.

Lobato, J.F.P., and G. R. Pearce. 1980b. Effects of some management procedures on the responses of sheep to molasses-urea blocks. Aust. J. Exp. Agric. Anim. Husb. 20:422-426.

Lobato, J.F.P., G. R. Pearce, and R. G. Beilharz. 1980a. Effect of early familiarization with dietary supplements on the subsequent ingestion of molasses-urea blocks by sheep. Appl. Anim. Ethol. 6:149-161.

Lobato, J.F.P., G. R. Pearce, and D. E. Tribe. 1980b. Measurement of the variability in intake by sheep of oat grain, hay and molasses-urea blocks using chromic oxide as a marker. Aust. J. Exp. Agric. Anim. Husb. 20:413-416.

Manspeaker, J. E., M. G. Robl, G. H. Edwards, and L. W. Douglass. 1987. Chelated minerals: Their role in bovine fertility. Vet. Med. 82:951-952, 954-956.

McDowell, L. R. 1996. Feeding minerals to cattle on pasture. Anim. Feed Sci. Technol. 60:247-271.

McDowell, L. R. 2003. Grazing ruminants require free-choice minerals. Feedstuffs.75(47).

McDowell, L. R. 1985. Nutrition of Grazing Ruminants in Warm Climates. Academic Press, New York.

Myers, W. D., P. A. Ludden, V. Nayigihugu, and B. W. Hess. 2004. Technical note: A procedure for the preparation and quantitative analysis of samples for titanium dioxide. J. Anim. Sci. 82:179-183.

Myers, W.D., P. A. Ludden, and V. Nayigihugu.2006. Excretion patterns of titanium dioxide and chromic oxide in duodenal digesta and feces of ewes. Small Ruminant Research 63:135-141.

Nolan, J. V., F. M. Ball, R. M. Murray, B. W. Norton, and R. A. Leng. 1974. Evaluation of a urea-molasses supplement for grazing cattle. Proc. Aust. Soc. Anim. Prod. 10:91-94. 
Nolan, J. V., B. W. Norton, R. M. Murray, F. M. Ball, F. B. Roseby, W. Rohan-Jones, M. K. Hill, and R. A. Leng. 1975. Body weight and wool production in grazing sheep given access to a supplement of urea and molasses: Intake of supplement/response relationships. J. Agric. Sci., 84:39-48.

NRC. 2007. Nutrient Requirements of Small Ruminants. National Academy Press, Washington, D. C.

Pond, K. R., J. C. Burns, and D. S. Fisher. 1987. External markers- use and methodology in grazing studies. Proc. Grazing Livestock Nutrition Conference. July 23-24, 1987. Jackson, WY. p. 49-53.

Provenza, F.D. 1996. Acquired aversions as the basis for varied diets of ruminants foraging on rangelands. J. Anim. Sci. 74:2010-2020.

Rocks, R.L., J. L. Wheeler, and D. A. Hedges. 1982. Labelled waters of crystallization in gypsum to measurethe intake by sheep of loose and compressed mineral supplements, Aust. J. Exp. Agric. Anim. Husb. 22:35-42.

Sampaio, Cláudia Batista, E. Detmann, T. N. P. Valente, M. Augusto de Souza, S. C. V. Filho, and M. F. Paulino. 2011. Evaluation of fecal recovering and long term bias of internal and external markers in a digestion assay with cattle. $R$. Bras. Zootec 40:174-182.

Sawyer, J. E., and C. P. Mathis. 2001. Supplement delivery systems. Cooperative Extension Service - New Mexico State University.Circular 571. Available at: http://aces.nmsu.edu/pubs/_circulars/Cr-571.pdf Accessed September 15, 2011.

Short, F.J., P. Gorton, and J. Wiseman. 1996. Determination of titanium dioxide added as an inert marker in chicken digestibility studies. Anim. Feed Sci. Technol. 59:215-221.

Smith, A. M., and J. T. Reid. 1955. Use of chromic oxide as an indicator of fecal output for the purpose of determining the intake of pasture herbage by grazing cow. J. Dairy Sci. 38:515-524.

Sowell, B. F, J. G. P Bowman, E. E. Grings, and M.D. MacNeil. 2003. Liquid supplement and forage intake by range beef cows. J. Anim. Sci. 2003. 81:294303.

Tait, R. M., and L.J. Fisher. 1996. Variability in individual animal's intake of minerals offered free-choice to grazing ruminants. Anim. Feed Sci. Technol. 62:69-76. 
Taylor, N., P. G. Hatfield, B. F. Sowell, J. G. P. Bowman, J. S. Drouillard, and D. V. Dhuyvetter. 2002. Pellet and block supplements for grazing ewes. Anim. Feed Sci. and Tech.96:193-201.

Theiler, A., H. H., Green, and P. J. Du Toit. 1924. Phosphorus in the livestock industry. Union S. Afr. J. Dept. Agr., 8: 460-504.

Tilley, J. M. A., and R. A. Terry. 1963. A two-stage technique for the in vitro digestion of forage crops. J. Brit. Grassland Soc. 18:104-111.

Titgemeyer, E.C., C. K. Armendariz, and D. J. Bindel. 2001. Evaluation of titanium dioxide as a digestibility marker for cattle. J. Anim. Sci. 79:1059-1063.

USDA, 1994.United States Department of Agriculture and APHIS. Beef cow/calf health and productivity audit. Part II. Beef cow/calf reproductive and nutritional management practices. Center for Epidemiology and Animal Health, January 1994. Fort Collins, CO.

Van Soest, P.J., J.B. Robertson, and B.A. Lewis. 1991. Methods for dietary fiber, neutral detergent fiber, and non-starch polysaccharides in relation to animal nutrition. J. Dairy Sci. 74:3583-3597.

Wagnon, K. A. 1965. Social dominance in range cows and its effect on supplemental feeding. Calif. Agric. Exp. Sta. Bull. \# 819.pp 1-32.

Wagnon, K. A., R. G. Loy, W. C. Rollins, and F. D. Carroll. 1966. Social dominance in a herd of Angus, Hereford, and Shorthorn cows. Anim. Behav. 14:474-479.

Weber, D.W., T.O. Dill, J.E. Oldfield, R. Frobish, K. Vandebergh, and W. Zollinger. 1992. Daily intake of free-choice salt and protein blocks by beef cows was highly variable. Prof. Anim. Sci. 8(2):15-20.

White, C. L., D. G. Masters, D. W. Peter, D. B. Purser, S. P. Roe, and M. J. Barnes. 1992. A multi element supplement for grazing sheep. I. intake, mineral status and production responses. Aust. J. Exp. Agric. Anim. Husb. 43:795-808.

Zhu, X., C. W. Deyoe, K. C. Behnke, and P. A. Seib. 1991. Poured feed blocks using distillery by-products as supplements for ruminants. J. Sci. Food Agric. 54:535547. 